US Army Corps of Engineers ${ }_{\circledast}$

Engineer Research and

Development Center

\section{ERDC}

INNOVATIVE SOLUTIONS

for a safer, better world

Integrated Climate Assessment for Army Enterprise Planning

\title{
Deployment Infrastructure
}

Natalie R. Myers, Michelle E. Swearingen, and James P. Miller

February 2017
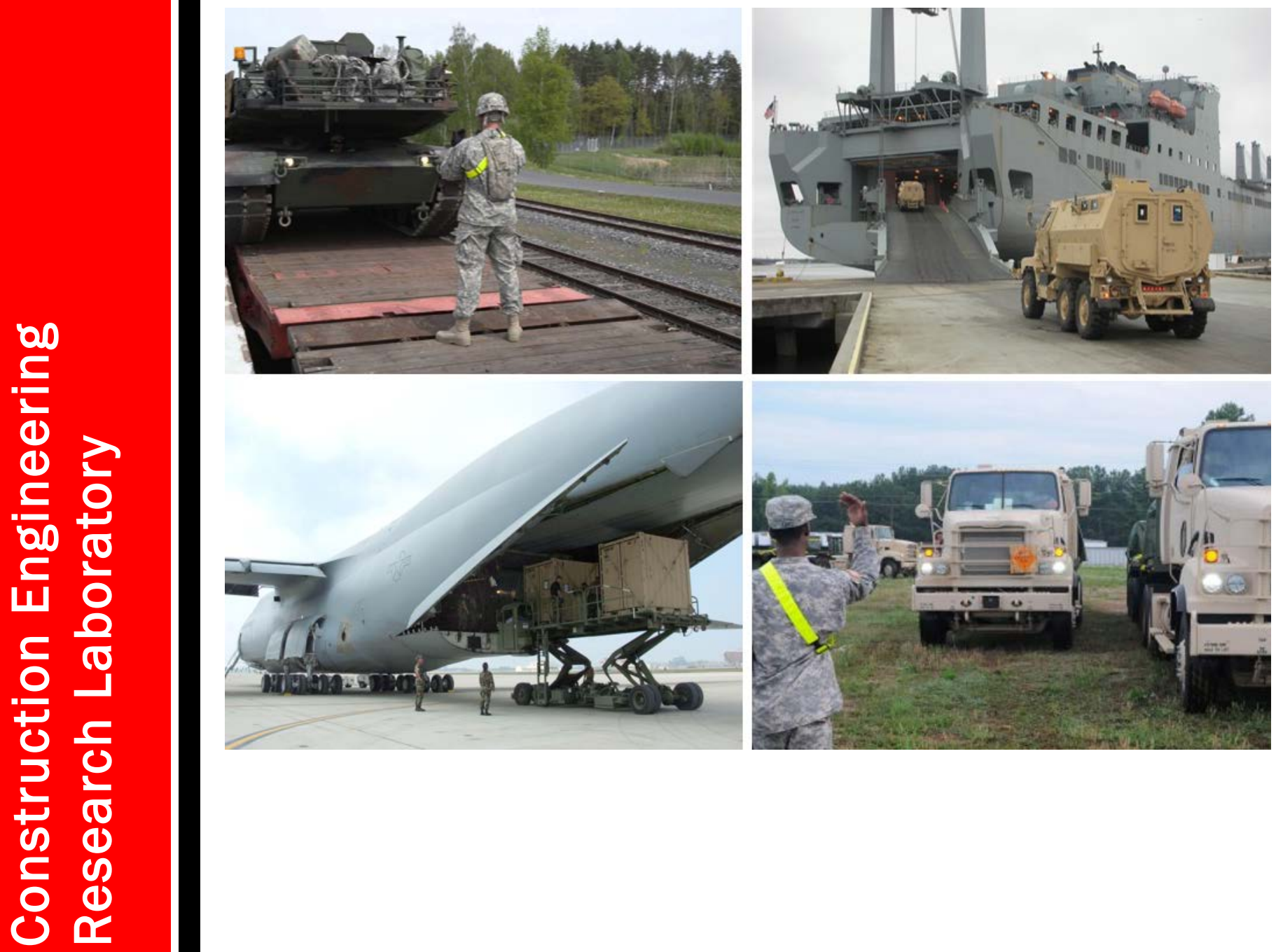

Approved for public release; distribution is unlimited. 
The U.S. Army Engineer Research and Development Center (ERDC) solves the nation's toughest engineering and environmental challenges. ERDC develops innovative solutions in civil and military engineering, geospatial sciences, water resources, and environmental sciences for the Army, the Department of Defense, civilian agencies, and our nation's public good. Find out more at www.erdc.usace.army.mil.

To search for other technical reports published by ERDC, visit the ERDC online library at http://acwc.sdp.sirsi.net/client/default. 


\section{Deployment Infrastructure}

Natalie R. Myers, Michelle E. Swearingen, and James P. Miller

U.S. Army Engineer Research and Development Center (ERDC)

Construction Engineering Research Laboratory (CERL)

2902 Newmark Dr.

Champaign, IL 61826

Final Report

Approved for public release; distribution is unlimited.

Prepared for Headquarters, U.S. Army Corps of Engineers

Washington, DC 20314-1000

Under R.INN.2015.26, “Climate Assessment for Army Enterprise Planning” 


\section{Abstract}

The Army's approach to deployment has been evolving over the past 30 years in response to the global dispersion of threats coupled with the necessity to rapidly deploy, execute, and sustain operations worldwide. The result is a transformation from a forward-deployed Cold War force to a capabilities-based, power-projection force located largely in the United States. Increased deployment activity has become the normal operational standard within the continental United States, which may regularly affect the planning and operations for local authorities. The Army's deployment abilities depend on the readiness of all stake-holders including the resilience of transportation infrastructure systems. Yet, transportation infrastructures are being damaged by sea level rise, heavy downpours, and extreme heatconditions that are anticipated to increase with continued climate change. This work investigated the degree to which climate change may impact the ability of Army installations to deploy forces in the future, and concluded that : (1) climate change may potentially pose a significant threat to future deployability, but that stationing decisions regarding deployment need not be influenced by climate change projections at this time.

DISCLAIMER: The contents of this report are not to be used for advertising, publication, or promotional purposes. Citation of trade names does not constitute an official endorsement or approval of the use of such commercial products. All product names and trademarks cited are the property of their respective owners. The findings of this report are not to be construed as an official Department of the Army position unless so designated by other authorized documents. 


\section{Contents}

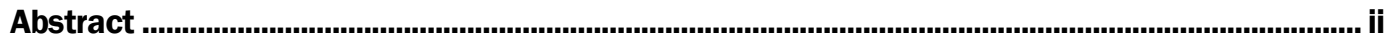

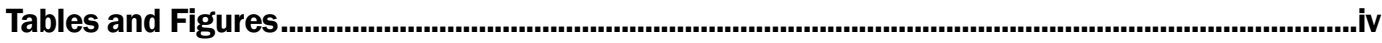

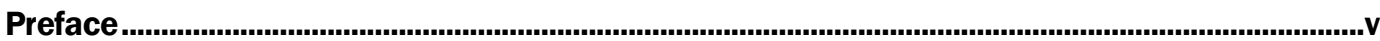

1 Introduction .............................................................................................................................. 1

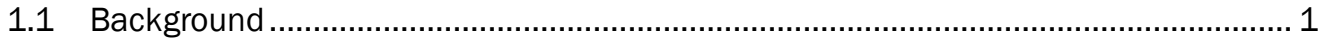

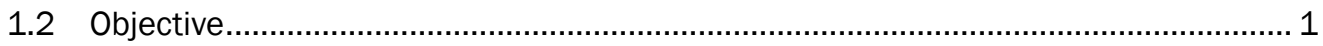

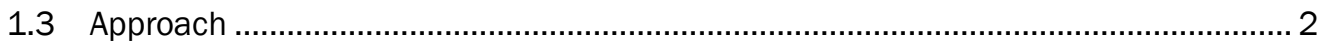

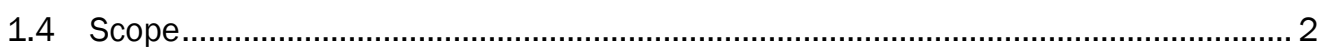

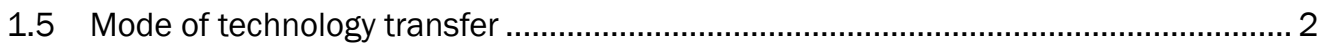

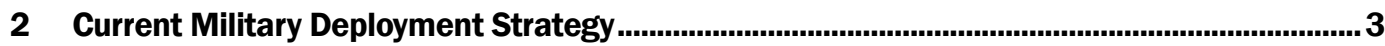

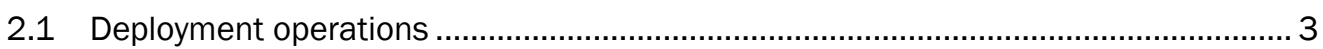

2.2 Doctrine and strategic planning ....................................................................... 8

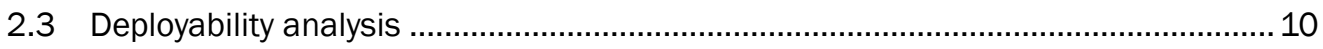

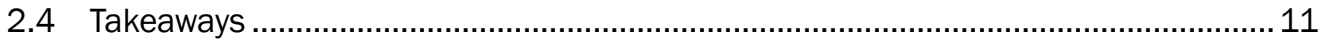

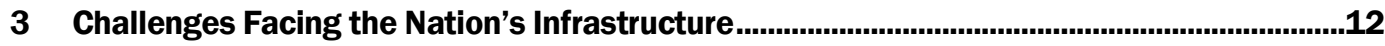

3.1 Challenges from the Department of Transportation's perspective..........................12

3.2 Challenges from climate scientist's perspective................................................... 15

3.3 Challenges from the Army's perspective ....................................................... 16

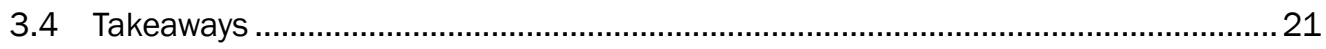

4 Army Stationing Analysis...................................................................................................23

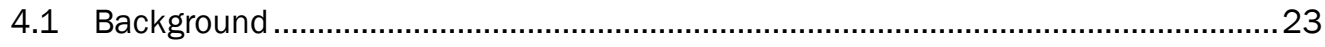

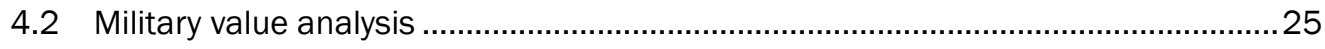

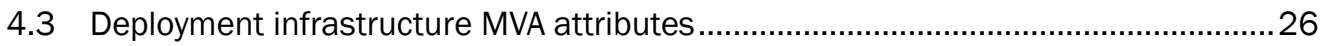

4.4 Optimal stationing of Army forces ....................................................................... 27

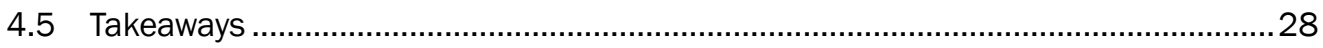

5 Conclusion ......................................................................................................................................30

5.1 Does climate change pose a significant threat to future deployability?....................30

5.2 Should climate change influence stationing decisions regarding

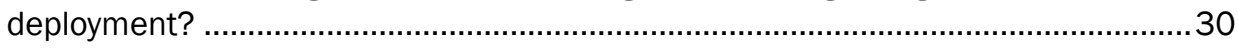

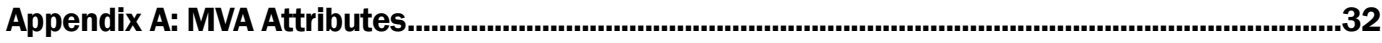

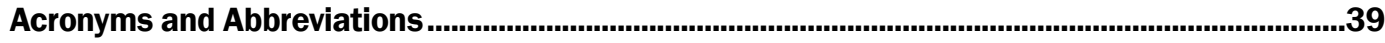

References ..................................................................................................................................42

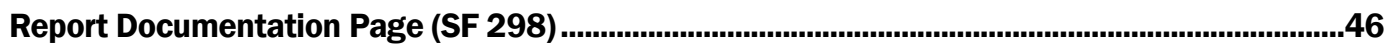




\section{Tables and Figures}

\section{Tables}

1 U.S. Military PPPs and their Designated Sea and Aerial Ports of Embarkation (SPOE and APOE)

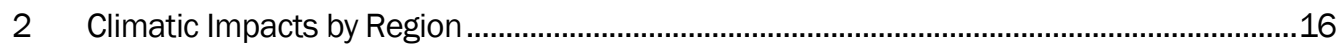

A-1 Air deployment scores for installation metrics ...................................................................34

A-2 Surface deployment scores for installation metrics ..........................................................36

A-3 Container transfer deployment scores for installation metrics ............................................38

\section{Figures}

1 Effective coordination procedures or plans require collaborative efforts among

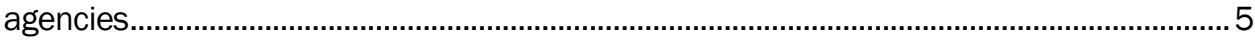

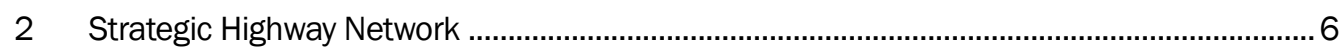

3 Strategic Rail Corridor Network .......................................................................................... 7

4 The Intelligent Road/Rail Information Server Screen Capture .............................................9

5 A sinkhole caused by a broken water main in Brooklyn, NY that swallowed a sport utility vehicle. Nationally, such incidents have become more frequent.......................13

6 Example input sheet from VAST .........................................................................................15

7 A lakebed used as an emergency runway at Edwards Air Force base inundated by floods did not dry out completely for 8 months..............................................................20

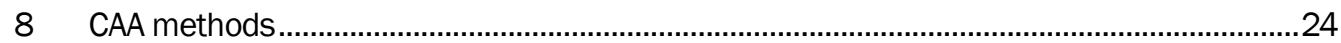

A-1 Air deployment infrastructure score..................................................................................34

A-2 Surface deployment infrastructure score ..........................................................................36

A-3 Container transfer deployment infrastructure score ............................................................38 


\section{Preface}

This study was conducted for the Assistant Secretary of the Army - Acquisition, Logistics, and Technology (ASA[ALT]) under R.INN.2015.26, "Climate Assessment for Army Enterprise Planning." The technical monitor was Ms. Wanda Johnson, ASA(IE\&E).

The work was performed by the Ecological Processes Branch (CNN) of the Installations Division (CN), U.S. Army Engineer Research and Development Center - Construction Engineering Research Laboratory (ERDCCERL). At the time of publication, Dr. Chris Rewerts was Chief, CEERDCNN; Michelle J. Hanson was Chief, CEERD-CN; and Alan B. Anderson, CEERD-CZT was the Technical Director for Environmental Quality/Sustainable Lands and Ranges. The Deputy Director of ERDC-CERL was Dr. Kirankumar Topudurti and the Director was Dr. Ilker Adiguzel.

COL Bryan S. Green was Commander of ERDC, and Dr. Jeffery P. Holland was the Director. 
THIS PAGE INTENTIONALLY LEFT BLANK 


\section{Introduction}

\subsection{Background}

The Army's approach to deployment has been evolving over the past 30 years in response to the global dispersion of threats coupled with the necessity to rapidly deploy, execute, and sustain operations worldwide. The result is a transformation from a forward-deployed Cold War force to a capabilitiesbased, power-projection force located largely in the United States. The military has reduced its size, redistributed its forces, closed and realigned bases, reorganized its overseas equipment, and improved active and reserve component integration to become leaner, more versatile, and more deployable.

Increased deployment activity has become the normal operational standard within the continental United States, which may regularly affect the planning and operations for local authorities. As a consequence, all states are experiencing increased cross-state movements of military assets with destinations beyond state borders. Within a state with major military installations, such as those with power projection platforms (PPPs), current deployment strategies may require 24/7 operations for increased equipment and personnel movements.

The Army's deployment abilities depend on the readiness of all stakeholders including the resilience of transportation infrastructure systems. Yet, transportation infrastructures (e.g., roads, rail lines, and airport runways) are being damaged by sea level rise, heavy downpours, and extreme heat. These damages are projected to increase with continued climate change. Climate change and its impacts may threaten the ability of U.S. forces to deploy. This work was undertaken to investigate the degree to which climate change may impact the ability of Army installations to deploy forces in the future.

\subsection{Objective}

The objective of this work was to investigate the degree to which climate change may impact the ability of Army installations to deploy forces in the future, specifically, to answer the following concerns:

- Does climate change pose a significant threat to future deployability? 
- Should stationing decisions regarding deployment be influenced by climate change projections? If so, how? If not, under what circumstances should climate change be considered?

\subsection{Approach}

This work was accomplished in the following steps:

1. The current military deployment strategies were reviewed, particularly with respect to the dynamic and changing nature of military deployment needs.

2. A review was conducted of how climate change is expected to impact transportation infrastructure.

3. Approaches recently used by the Army to conduct stationing and base realignment and closure studies were reviewed. In those studies the Army places a high value on the capacity of installations to support deployment assets.

4. Conclusions were drawn by answering the objective questions.

\subsection{Scope}

This study is limited to consideration of the ability of Army installations in the Continental United States (CONUS) to support deployment infrastructure into the future. The overall intent is to consider expanding the measurements of current deployment capacities to account for how these capacities are likely to change over the next 5 decades. Drivers to those changes are limited to direct and indirect consequences of climate changes.

\subsection{Mode of technology transfer}

This report provides a foundation for follow-on research. Publication of this report by ERDC constitutes the transfer of this knowledge to the user community. 


\section{Current Military Deployment Strategy}

\subsection{Deployment operations}

The ability to deploy equipment and personnel rapidly is an imperative of the national military strategy. That strategy expects the military to defend the homeland, deter aggressions, and swiftly defeat adversaries. Implied in these missions is the requirement to deploy forces within the United States and from the United States to anywhere in the world. To assist the military services in their planning and to better prepare for future operations, the U.S. Department of Defense (DoD) has established an objective to be able to deploy to a theater within 10 days, to have sufficient combat power to defeat an enemy during the next 30 days, and to be ready for the next fight within another 30 days (TRADOC Pam 525-3-6 [HQDA 2010]). Key to meeting these deployment goals is the capability of units to move rapidly from their installations to land, sea, and aerial ports of embarkation (POEs).

Military units use various methods to move equipment and personnel to their POEs. Heavy equipment will usually be shipped by rail; however, some equipment must be deployed on public roads either driven by military personnel or consigned to commercial carriers to arrive at the POE on specific dates and times for proper loading onto ships or planes. When the military uses public roads, it organizes the equipment into convoys for control and protection. The Federal Highway Administration (FHWA) provides detailed information about the military's organization of convoys and standard highway procedures for convoys (FHWA 2005).

Typically, the destination for military deployments is a commercial seaport for loading on Military Sealift Command (MSC) ships for overseas movement. When cargo is time sensitive and can be transported by air, the military often uses aerial ports of embarkation (APOEs). Other special situations include:

- Military Depot and Contractor Repair Facilities. Equipment that has been deployed often needs to be repaired back in the United States and prepared for redeployment as needed. This often creates an unexpected cycle of large military equipment moving in and out of remote depot repair or contractor service facilities via rail or commercial carriers.

- National Special Security Events. Under the National Response Plan, events within the United States may be designated as national security 
events and may require coordinated military deployments at the state or Federal level to provide additional security.

\subsubsection{Power projection platform installations}

A PPP is an Army installation that strategically mobilizes and deploys one or more high priority active component brigades or reserve component units. Installations designated as PPPs will be prioritized and resourced to perform power projection functions together with designated strategic sea and aerial ports in support of national strategy. There are 15 designated Army PPPs within the CONUS, along with two Marine Corps installations that serve a similar function. Table 1 lists PPP installations and their designated POE.

Table 1. U.S. Military PPPs and their Designated Sea and Aerial Ports of Embarkation (SPOE and APOE).

\begin{tabular}{|l|l|l|}
\hline PPP Installations & Designated SPOE* & Designated APOE \\
\hline Fort Benning & Port of Savannah, GA & Lawson Army Airfield (AAF) \\
\hline Fort Bliss & Port of Galveston, TX & Biggs AAF \\
\hline Fort Bragg & Port of Charleston, SC & Pope Air Force Base (AFB) \\
\hline Fort Campbell & Port of Jacksonville, FL & Campbell AAF \\
\hline Fort Carson & Port of Hampton Roads, VA & Peterson AFB \\
\hline Fort Dix & Port of New York/New Jersey & McGuire AFB \\
\hline Fort Drum & Port of New York/New Jersey & Wheeler-Sack AAF \\
\hline Fort Eustis & Port of Hampton Roads, VA & Langley AFB \\
\hline Fort Hood & Port of Beaumont, TX & Robert Gray AAF \\
\hline Fort Lewis & Port of Tacoma, WA & McChord AFB \\
\hline Fort McCoy & Port of Hampton Roads, VA & Volk Field \\
\hline Fort Polk & Port of Beaumont, TX & England Airpark \\
\hline Fort Riley & Port of Hampton Roads, VA & Forbes Field \\
\hline Fort Sill & Port of Beaumont, TX & Altus AFB \\
\hline Fort Stewart & Port of Savannah, GA & Hunter AAF \\
\hline Camp Lejeune & Port of Morehead City, NC & Marine Corps Air Station (MCAS) Cherry Point \\
\hline Camp Pendleton & Port of San Diego, CA & March AFB \\
\hline Source: www.globalsecurity.org 2011 & \\
\hline
\end{tabular}

\subsubsection{Key players}

Seaports and highways deploy and redeploy the majority of military assets, and as a result, many agencies outside of the formal military structure play a critical role in ensuring that the military deploys safely and efficiently with minimal impact to traditional traffic. Figure 1 conceptualizes major 
agencies directly involved in military deployments. Each agency contributes to the effectiveness of military coordination plans and procedures. Roles vary and include multiple levels of support for coordination, planning, resource and asset preparedness, operational assistance, contingency response, and performance assessment. The Secretary of Defense, for example, organizes and assigns deployment operational tasks to multiple DoD agencies (e.g., U.S. Transportation Command [USTRANSCOM], U.S. Army Training and Doctrine Command [TRADOC], U.S. Army Forces Command [FORSCOM], U.S. Army Materiel Command [AMC], U.S. Army Special Operations Command [USASOC], etc.). Army Regulation 525-93, Army Deployment and Redeployment (HQDA 2014) establishes policy; identifies responsibilities; and synchronizes procedures for all commands and agencies responsible for planning, preparing, and supporting deploying and redeploying Army forces.

Figure 1. Effective coordination procedures or plans require collaborative efforts among agencies.

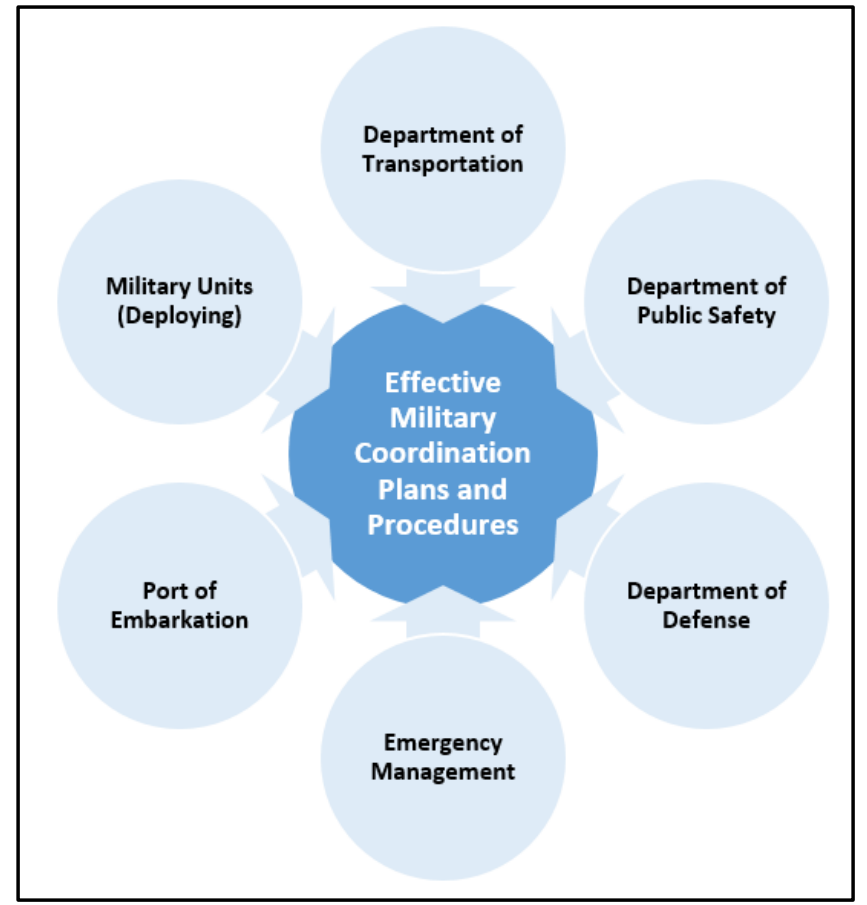

In support of the national defense program, the U.S Department of Transportation (DOT) ensures that the Nation's highway and rail infrastructure can support defense deployments. The Strategic Highway Network (STRAHNET) is a system of public highways designated by the FHWA in partnership with DoD to provide access, continuity, and emergency transportation of personnel and equipment in times of peace and war. Figure 2 
depicts the STRAHNET. STRAHNET comprises about 45,400 miles of Interstate and defense highways, 15,000 miles of other public highways, and about 1,700 miles of connectors - additional highway routes - that link more than 200 military installations and ports to the network (FHWA 2005). In CONUS, units within 1 day (400 miles) of a POE normally road march or convoy wheeled vehicles to the POE.

Figure 2. Strategic Highway Network.

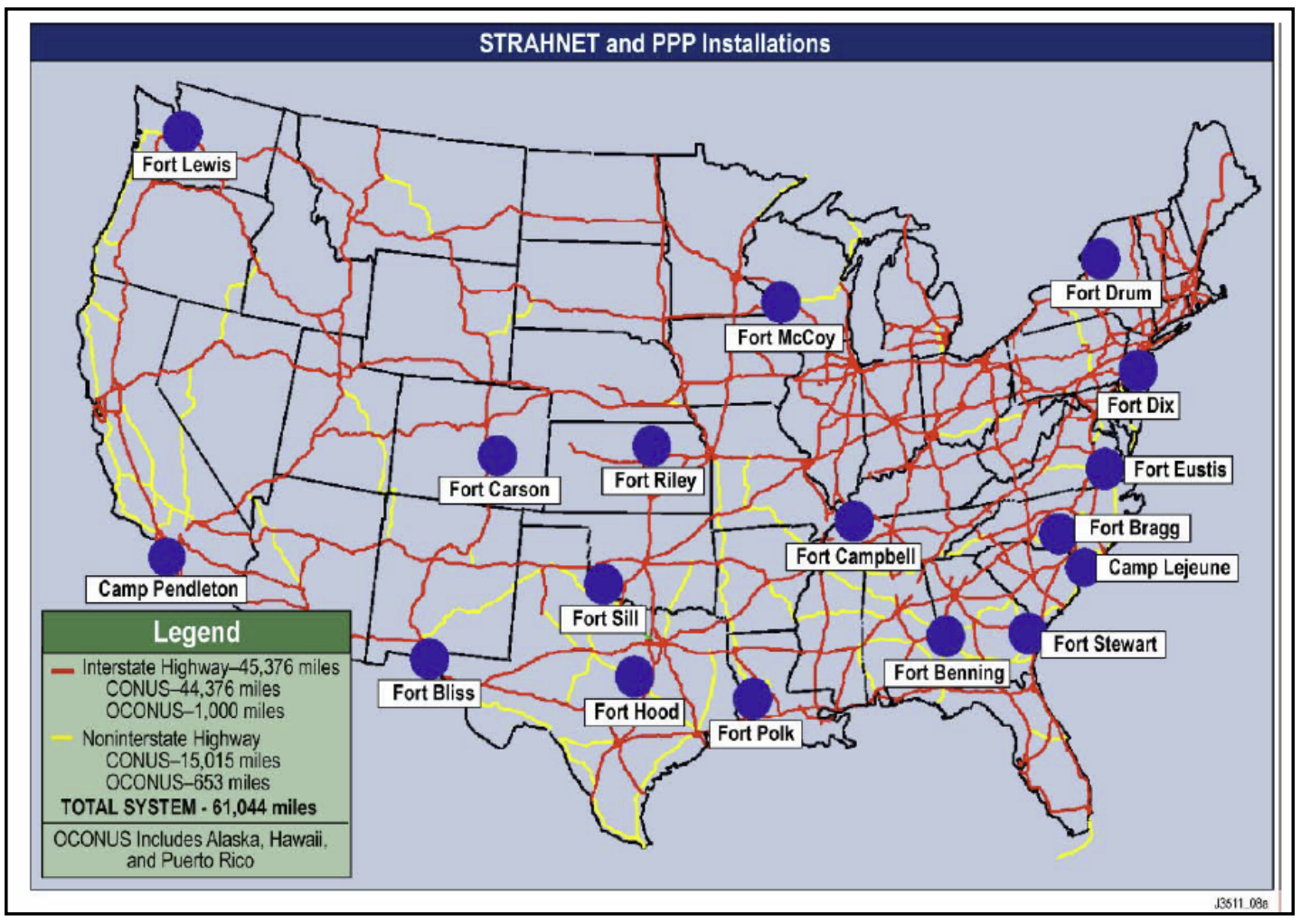

Source: (FHWA 2005).

The Strategic Rail Corridor Network (STRACNET) consists of 38,800 miles of rail lines important to national defense and provides service to 193 defense installations that require rail service to complete their missions. Figure 3 depicts the STRACNET. The military places heavy and direct reliance on railroads to integrate bases and connect installations to predominantly SPOE. Mainlines, connectors, and clearance lines must all combine to support movement of heavy and/or oversized equipment. To ensure that military needs are factored into railroad industry decisions that may impact national defense, DoD relies on the Military Traffic Management Command (MTMC). In this capacity, MTMC identifies facilities of the railroad infrastructure important to national defense, informs the 
commercial and civil sectors of Defense needs, and encourages the retention and upkeep of railroad assets vital to support military movements. The Railroads for National Defense Program (RND) ensures the readiness capability of the national railroad network to support defense deployment and peacetime needs. The Program works to integrate defense rail needs into civil sector planning that affects the nation's railroad system. Rail transportation is extremely important to DoD since the predominance of heavy and tracked vehicles will deploy by rail to their SPOE(s). The RND Program in conjunction with the U.S. Federal Railroad Administration (FRA), established the STRACNET to ensure that DoD's minimum rail needs are identified and coordinated with appropriate transportation authorities (FRA 2009).

Figure 3. Strategic Rail Corridor Network.

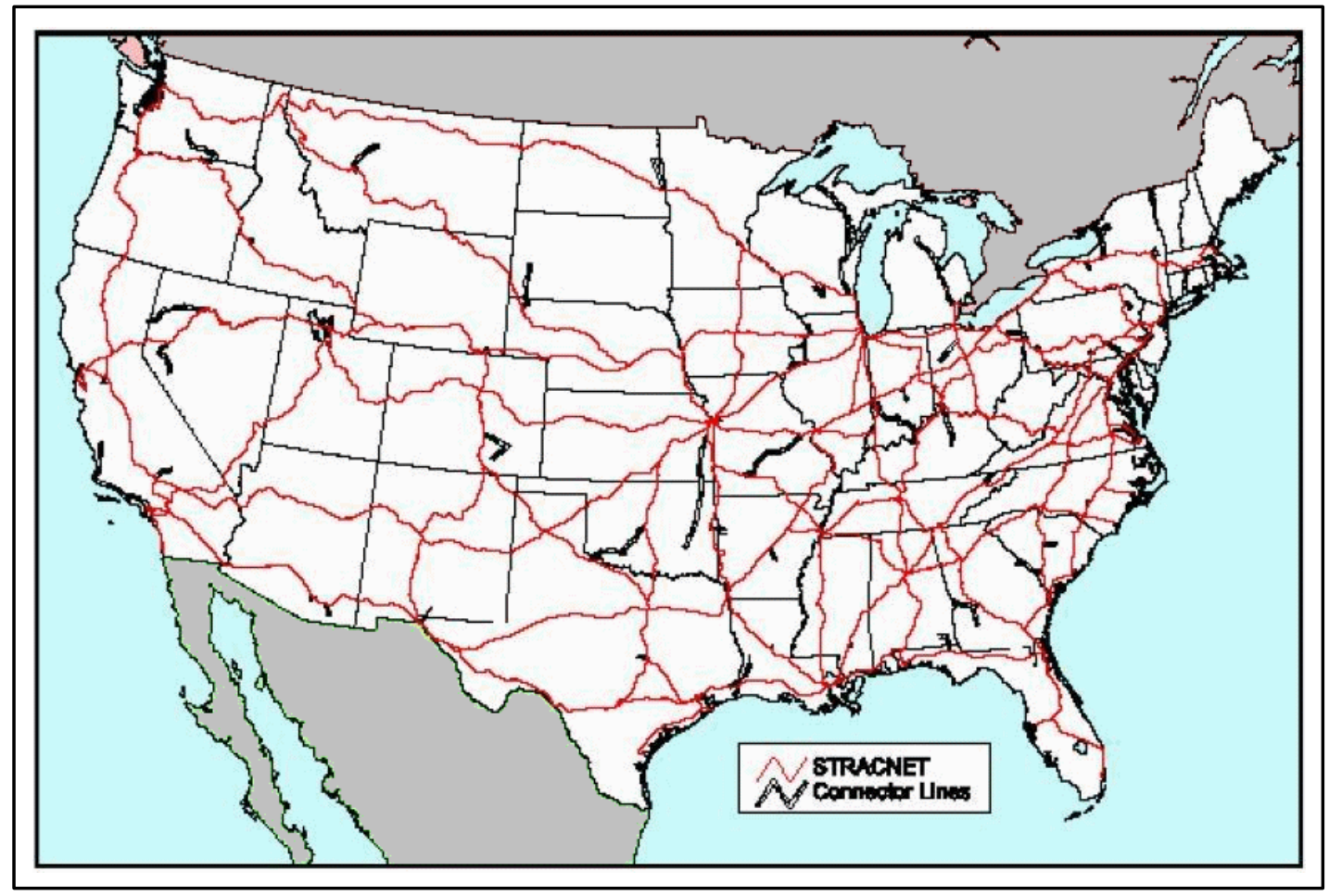

Source: www.globalsecurity.org

\subsubsection{Planning factors and tools}

Specialized planning tools and technologies assist in planning and operational support of military deployments. These are developed by USTRANSCOM, the Transportation Engineering Agency (TEA). TEA plans, coordinates, directs, and monitors movement and deployment of forces and materiel necessary to meet military objectives. These services include 
installation transportation studies; evaluations of marine ports, terminals, and other modal facilities; identification of important public highways and commercial rail lines; and engineering guidance related to force mobilization and deployment. The Surface Deployment and Distribution Command Transportation Engineering Agency (SDDCTEA) develops and uses several modeling and simulation tools to support deployability engineering and analysis. These state-of-the art planning and analysis tools model in detail the interaction of the infrastructure and transport systems with the detailed transportability characteristics of the force (units and equipment). They include, but are not limited to, the following tools:

- Transportability Analysis Report Generator (TARGET)

- Analysis of Mobility Platform (AMP)

- AMP Port Analysis Tools (AMP-PAT)

- Joint Mobility Closure Estimator (JAMCE)

- Rapid Course of Action Analysis Tool (RCAT).

Another example military planning tool is the Intelligent Road/Railroad Information System (IRRIS), which provides a suite of web-based tools for planning and tracking of assets. Figure 4 shows a screen capture of the IRRIS tool. IRRIS enables users to obtain detailed, timely, and relevant information about road conditions, construction, incidents, and weather conditions that might interfere with the movement of people and goods. It leverages the latest advances in information technology, Global Positioning Systems (GPSs), Geographic Information Systems (GISs), and Location-Based Services (LBSs) to provide decision makers with information necessary for efficient and rapid deployment of troops, equipment, and sustainment materiel between origins and destinations. This integrated system provides planners with real-time tools for routing troops, equipment, and sustainment materials in the most efficient and effective manner and provides this information anytime, anywhere, on any Web-enabled device (http://www.IRRIS.com).

\subsection{Doctrine and strategic planning}

Deployment doctrine changes with the ever changing world environment. Today, the Army Power Projection Program (AP3) Rapid Expeditionary Deployment Initiative (REDI) is the catalyst to improve expeditionary deployment readiness. Through REDI, the AP3 community is refocusing the Army to develop inherent deployment skills via doctrine, organization, training, leadership and education, personnel, facilities, and policy. 
Figure 4. The Intelligent Road/Rail Information Server Screen Capture.

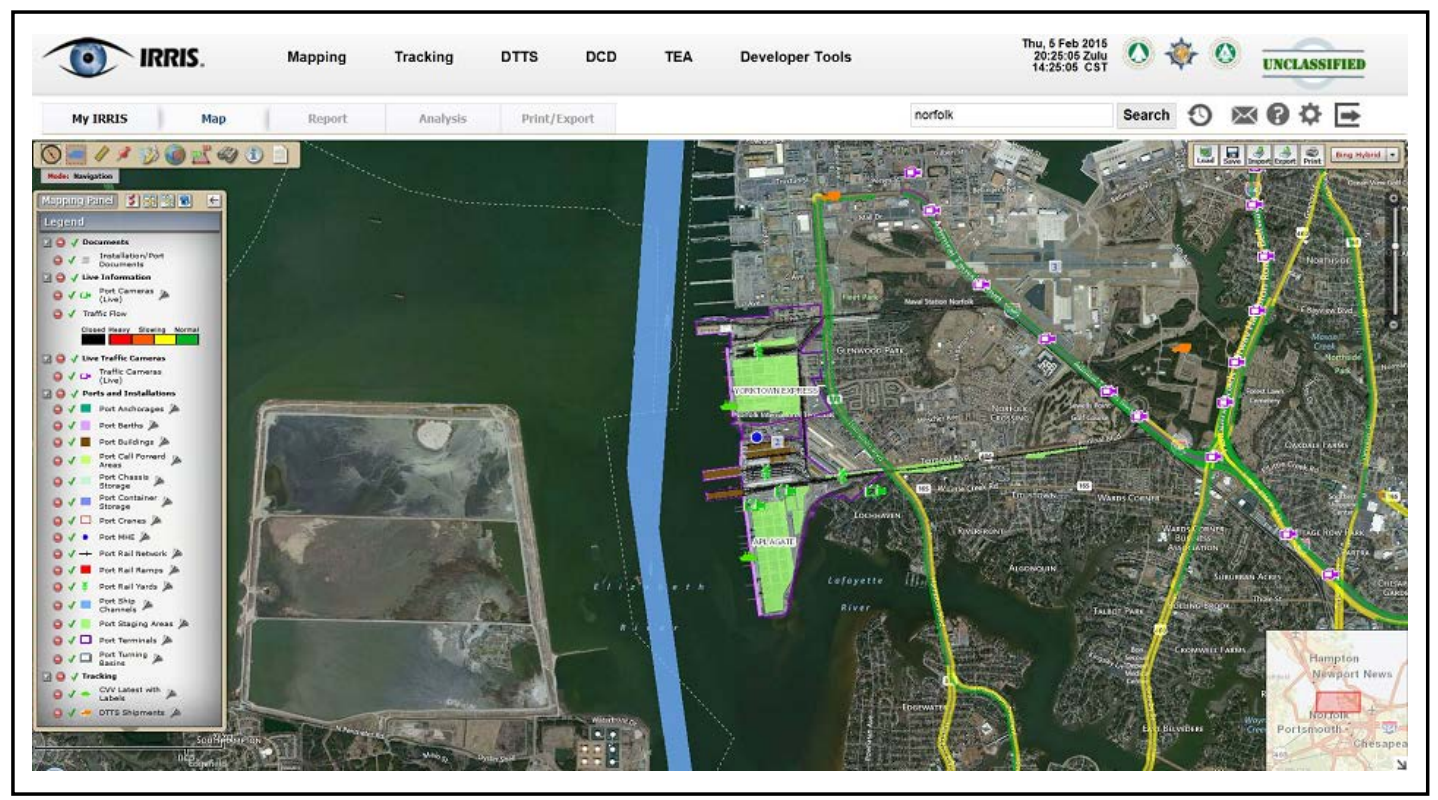

Source: http://www.sddc.army.mil/sites/TEA/Functions/SpecialAssistant/Pages/IRRIS.aspx

In 2012, the Army validated the assumption that it needs to improve its readiness to deploy quickly. The $\mathrm{AP} 3$ general officer steering committee observed that the Army is changing from advanced notice rotational deployments to a persistent state of expeditionary deployment readiness. These operational factors necessitate a shift from a supply-based system to a dynamic system where Army logisticians make the right integrated decisions by having broad system knowledge rather than solely being a supply or transportation specialist. AP3's 2012 assessment captured 30 issues and insights affecting the deployment process. The top three issues (Trubenbach 2014) are that:

- The Army needs to delineate deployment roles and missions for FORSCOM, AMC, and the U.S. Army Installation Management Command (IMCOM).

- Unit-level deployment tasks have been accomplished not by deploying units, but instead by enabling the installations to use civilian and contract support.

- Leaders should emphasize the importance of units training on deployment and redeployment tasks.

To assist units in becoming better prepared to rapidly deploy, the Deployment Process Modernization Office (DPMO) has taken deployment readiness to the next level by "operationalizing" REDI. DPMO is accomplishing 
this mission through multiple efforts, including a one-stop repository website for deployment planners called the "REDI Toolbox." The REDI Toolbox is a deployment assistance team program in which subject matter experts use the REDI lessons learned strategy to collect, analyze, and act on deployment-related findings from the field.

Before the formulation of the AP3-REDI initiatives, the 1992 Mobility Requirements Study (GAO 1993) and the follow-on 1995 Bottom-Up Review Update (GAO 1995) concluded that the military could increase deployability only through investment in airlift, sealift, equipment prepositioning, deployment infrastructure, and related initiatives. To implement study recommendations, the Army invested over $\$ 5$ billion between 1994 and 2003 to upgrade its deployment capability. Upgrades focused on installation departure airfields, road networks, railheads, and port facilities. Included were:

- modernized arrival/departure airfield control group facilities

- improved facilities for rapid rail loading

- upgraded and expanded facilities to support the Army's Afloat Prepositioning Program at Charleston Naval Weapons Station

- upgraded containerized ammunition port facilities on the West Coast.

Overall, the Army recognizes that the world environment will continue to change, and that the Army must continue to change with it. Unit readiness to rapidly deploy will continue to require assessments of force projection capabilities at key installations, depots, and ports to identify gaps in future programming regarding facilities, people, and equipment. However, the future focus will also include streamlining procedures and making deployment a more integral part of training programs.

\subsection{Deployability analysis}

The REDI Toolbox (https://www.us.army.mil/suite/page/689011 [DPMO 2016]) includes a number of deployment studies conducted for specific installations. A review of several of them resulted in the following observations:

- A majority of deployment study reports include inclement weather considerations and plans. The authors will assess whether or not climatic conditions are likely to interfere with deployment operations. At Fort Drum, for example, snow was understood to slow operations.

- Recommendations are often equipment based. Despite operational processes being regularly defined, none of the reviewed reports recommended procedural changes. 
- Analysis is rooted in the belief that every installation's facilities and operations are unique. Therefore, a majority of input data is obtained from installation personnel, and the approach was tailored to the circumstances.

- Modeling and simulation are routinely used to identify asset needs to meet criteria. All modeling and simulation assume ideal weather conditions.

\subsection{Takeaways}

This review of military deployment strategy yielded the following pertinent observations:

- Deployment operations are highly coordinated operations that require full support of Federal, state, and local agencies. The process consists of a large number of participants who must follow designated business procedures to provide accurate and prompt data and information.

- Technology mitigates hazard/congestion or route closures.

- Chokepoints within the deployment process are often changing. In the 1990 investments focused on upgrading prepositioning and loading equipment. The current focus is shifting toward streamlining procedures and making deployment a more integral part of training programs.

- Practices change with weather conditions; however, capabilities/readiness are not necessarily impacted by weather. Readiness is dependent on rehearsal-knowing what works for a unique environment. 


\section{Challenges Facing the Nation's Infrastructure}

\subsection{Challenges from the Department of Transportation's perspective}

Although not specific to strategic defense assets, the DOT asserts that the Nation faces serious challenges that threaten the quality and integrity of its surface transportation network. The following sections discuss these harmful trends in ranked order.

\subsubsection{Age and deterioration}

Deterioration of the Nation's surface transportation network comes naturally from age and use. Many highways, bridges, transit lines, and railroad lines are buckling under levels of traffic that were unforeseen by the engineers who designed them. Weather, air pollution, and the corrosive impact of road salt have caused decay throughout much of the transportation network (USDOT 2013).

Other problems are caused by what is below the surface transportation network, including water pipes and other utility conduits. Many of the Nation's water systems were built during periods when cities grew the fastest: at the end of the nineteenth century, in the 1920s, and after the Second World War. The U.S. Environmental Protection Agency estimates that unless cities invest more in water and sewer system improvement, almost half of the Nation's underground pipes will be in poor, very poor, or life elapsed status by 2020 (Yardley 2007). As these aging pipes burst, they create sinkholes in the roads above them that are sometimes so large they swallow whole cars (e.g., Figure 5).

Throughout the United States, agencies are working to repair and upgrade the Nation's aging transportation infrastructure. There are many success stories, such as advancements that have greatly improved pavement quality and extended the lives of the Nation's highways and bridges. However, despite some hopeful signs, the DOT has expressed great concern about the age and deterioration of the Nation's roads, bridges, railroads, transit systems, ports and waterways. The DOT has concluded that much more must be done to upgrade the Nation's entire transportation network to acceptable conditions. 
Figure 5. A sinkhole caused by a broken water main in Brooklyn, NY that swallowed a sport utility vehicle. Nationally, such incidents have become more frequent.

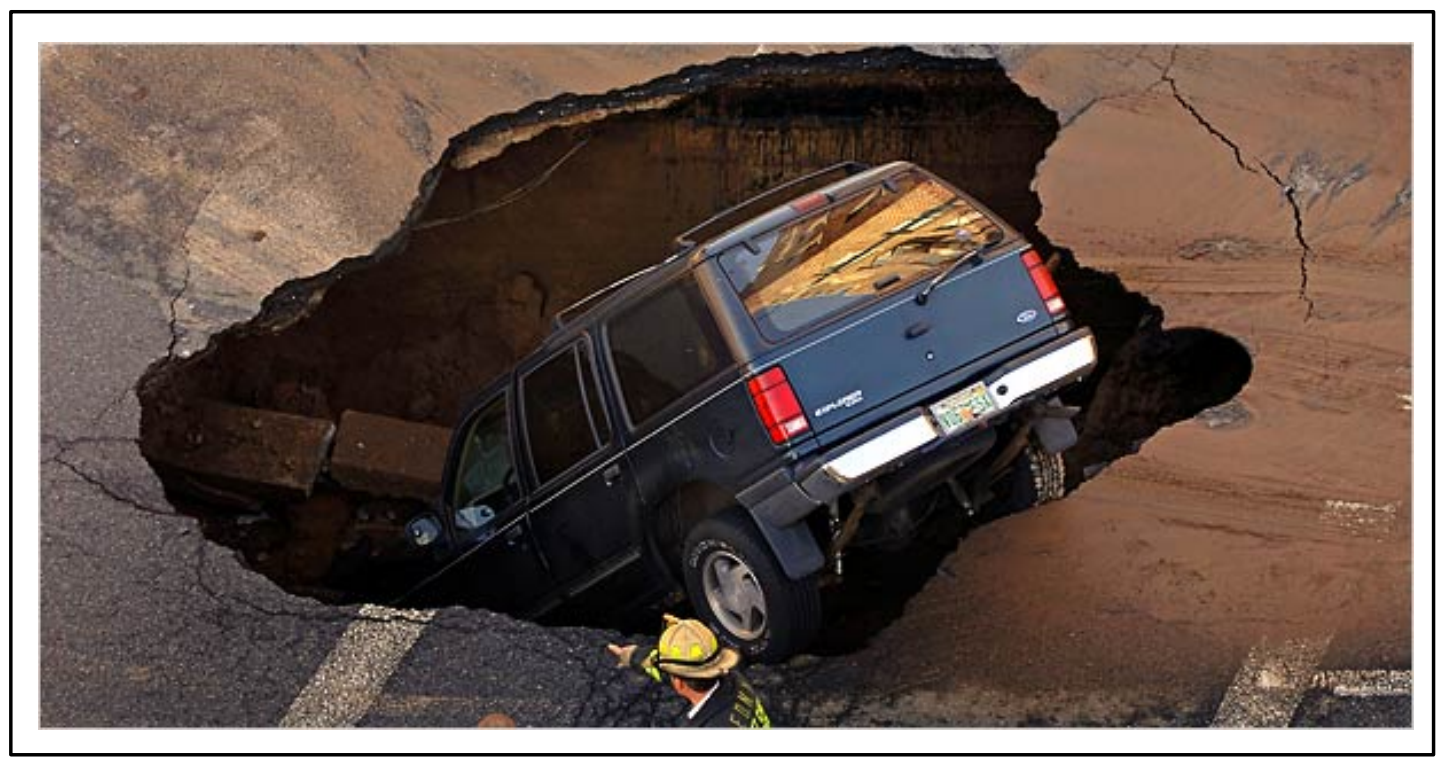

Source: (Yardley 2007).

To address this issue, a number of transit agencies and other asset owners (at the Federal, state, and local levels) have invested in asset management systems to more effectively manage their physical assets. Ideally these systems use quality inventory and condition data and well-defined objectives to provide a systematic process for improving resource allocation decisionmaking. However, significant barriers to this ideal state remain. Despite great advances in remote monitoring and sensor technologies, comparatively little attention is being given to the larger systems issues such as implementation pathways, stakeholder acceptance, financing, and so on. Note that there is limited data available for rail lines, airports, and seaports since these are primarily privately owned. Some of the national condition and performance databases are:

- Highway Performance Monitoring System (DOT)

- National Transit Database (DOT)

- Transit Economic Requirements Model (TERM) Database (Federal Transit Administration)

- Inland and intra-coastal waterway data (U.S. Army Corps of Engineers).

\subsubsection{Urban/population growth and crippling levels of congestion}

Over the past decade, vehicular traffic congestion has reached alarming levels across the United States. Gridlock, which is becoming a shared experience for tens of millions of motorists every day, impacts communities 
across the country. The planners who designed the country's modern transportation system likely never imagined the demands of the twentyfirst century. All elements of the surface transportation network are overwhelmed by congestion in one form of another, although it is the Nation's highway system that is perhaps the most visible sign of this crisis.

Throughout the United States, metropolitan areas have become traffic chokepoints, mired in gridlock that seems to worsen every year. The Texas Transportation Institute's 2012 Urban Mobility Report lays out the problem in stark terms. In 1982, there was only one metropolitan region where the average traveler experienced 40 or more hours of delay per year-Los Angeles. Today, that number has grown to 28 metropolitan areas in every corner of the Nation (TTI 2012).

Similarly, the Federal Aviation Administration (FAA) warns of increasing airport congestion (Gentry, Duffy, and Swedish 2014). On the other hand, news reports broadcast a mix of significant to no congestion at the Nation's seaports. In some cases, demand exceeds capacity, whereas in other cases there is overcapacity. Port congestion is geographically spread, and affecting both larger and smaller ports.

The Army Corps of Engineers asserts that many locks on many of the Nations waterways are simply too old to accommodate modern barge traffic. Older locks were designed to process 600-ft tows, while many tows today are twice that length. As a result, longer tows must be broken down into two or more segments and reassembled after passing through a lock (IWR 2000).

By contrast, the Nation's freight rail network is relatively uncongested at current volumes of cargo. Eighty-eight percent of today's primary freight rail corridor mileage is operating below practical capacity. About $12 \%$ is near or at practical capacity, and less than $1 \%$ is operating above capacity (FRA 2015). Over the next 3 decades, however, growing volumes of cargo are expected to lead to a significant deterioration in level of services on the freight rail network.

\subsubsection{Protecting the environment}

Burning fossil fuels for transportation causes pollutants and emits greenhouse gases, which affects ambient air quality and directly impacts health and wildlife. Emissions of greenhouse gases from the burning of fossil fuels by transportation also exacerbate global climate change. Within the 
United States, one-third of greenhouse gas emissions come from transportation sources (FHWA 2013).

The DOT's focus is primarily on adjusting transportation practices to potentially reduce climate change stressors. The FHWA is just beginning to consider the reverse-recently releasing a series of guidance and tools.

For example, the FHWA's is currently developing the Vulnerability Assessment Scoring Tool (VAST). VAST is an Excel ${ }^{\circledR}$ spreadsheet that walks users step-by-step process through the key steps and questions necessary to conduct an indicator-based vulnerability screening assessment. This would include choosing the climate stressors and assets to be evaluated, selecting indicators, collecting data on those indicators, developing an approach to convert indicator data into vulnerability scores, and reviewing the results (Figure 6). The tool is designed to be flexible, and to allow users to select any indicators, data sources, and climate stressors they choose. VAST includes hundreds of example indicators and example scoring approaches that can be used (FHWA 2014).

Figure 6. Example input sheet from VAST.

\begin{tabular}{|c|c|c|c|}
\hline Sensitivity Sconing Approoch & \multicolumn{2}{|c|}{ How ace scores calculated? } & \\
\hline \multicolumn{4}{|c|}{ How much should each indicator contribute to the overall sensitivity score? } \\
\hline Dast Experience with Precipitatien & $43 \%$ & $\begin{array}{l}\text { Dertent in sco. } \\
\text { vear hod tone. }\end{array}$ & $\begin{array}{l}\text { hat festrience } \\
\text { with }\end{array}$ \\
\hline Propenulty for Ponding & $24 \%$ & as & tecionicion: \\
\hline Percentage of impervious Surface & $14 \mathrm{~S}$ & Percent in & \\
\hline Percent in 100 - year flood rone & $17 \mathrm{k}$ & 100 ven & \\
\hline Percent in 500 - year flood zone & $12 \%$ & $\begin{array}{l}\text { food sone. } \\
\text { ins }\end{array}$ & \\
\hline Fotal Weight: & $100 \%$ & sorisce, t4s & \\
\hline
\end{tabular}

Source: (FHWA 2014).

\subsection{Challenges from climate scientist's perspective}

According to the U.S. Global Change Research Program, U.S. National Climate Assessment, the impacts from sea level rise and storm surge, extreme weather events, higher temperatures and heat waves, precipitation changes, Arctic warming, and other climate conditions are affecting the reliability 
and capacity of the U.S. transportation system in many ways (Melillo, Richmond, and Yohe 2014). These impacts will vary across regions of the United States. Table 2 lists and characterizes some of these disruptions.

Climate change impacts will increase the total costs to the Nation's transportation systems and their users, but these impacts can be reduced through rerouting, mode change, and a wide range of adaptive actions.

Table 2. Climatic Impacts by Region

\begin{tabular}{|c|c|}
\hline Region & Climate Impacts \\
\hline Northeast & $\begin{array}{l}\text { Communities are affected by heat waves, more extreme precipitation events, } \\
\text { and coastal flooding due to sea level rise and storm surge. }\end{array}$ \\
\hline Southeast & $\begin{array}{l}\text { Decreased water availability, exacerbated by population growth and land-use } \\
\text { change, causes increased competition for water. There are increased risks } \\
\text { associated with extreme events such as hurricanes. }\end{array}$ \\
\hline Midwest & $\begin{array}{l}\text { Longer growing seasons and rising carbon dioxide levels increase yields of } \\
\text { some crops, although these benefits, have already been offset in some } \\
\text { instances by occurrence of extreme events such as heat waves, droughts, and } \\
\text { floods. }\end{array}$ \\
\hline Great Plains & $\begin{array}{l}\text { Rising temperatures lead to increased demand for water and energy and } \\
\text { impacts on agricultural practices. }\end{array}$ \\
\hline Southwest & $\begin{array}{l}\text { Drought and increased warming foster wildfires and increased competition for } \\
\text { scarce water resources for people and ecosystems. }\end{array}$ \\
\hline Northwest & $\begin{array}{l}\text { Changes in the timing of stream flow related to earlier snowmelt reduce the } \\
\text { supply of water in summer, causing far-reaching ecological and } \\
\text { socioeconomic consequences. }\end{array}$ \\
\hline Alaska & $\begin{array}{l}\text { Rapidly receding summer sea ice, shrinking glaciers, and thawing permafrost } \\
\text { cause damage to infrastructure and major changes to ecosystems. Impacts to } \\
\text { Alaska Native communities increase. }\end{array}$ \\
\hline Hawaii & $\begin{array}{l}\text { Increasingly constrained freshwater supplies, coupled with increased } \\
\text { temperatures, stress both people and ecosystems and decrease food and } \\
\text { water security. }\end{array}$ \\
\hline Coasts & $\begin{array}{l}\text { Coastal lifelines, such as water supply infrastructure and evacuation routes, } \\
\text { are increasingly vulnerable to higher sea levels and storm surges, inland } \\
\text { flooding, and other climate-related changes. }\end{array}$ \\
\hline
\end{tabular}

\subsection{Challenges from the Army's perspective}

The U.S. government recognizes that the national climatic outlooks are based on a set of climate projections of outcomes that could occur under a set of possible scenarios, and not on climate predictions of specific outcomes. The future trends in emissions and global economic growth rates that can influence these trends are not reliably predictable. These projections represent a range of expected future climate changes based on observed and/or projected greenhouse gas trends and trends in energy use. 
Nevertheless, the U.S. government views climate change as settled science and has established policies to actively control climate change drivers and to plan for future climate change impacts.

Per Executive Order (EO) 13693, Planning for Federal Sustainability in the Next Decade (White House 2015), all Federal Departments and Agencies are required to evaluate climate change risks and vulnerabilities to manage short- and long-term effects of climate change on the agency's mission and operations. This includes "the incorporation of climate-resilient design and management elements into the operation, repair, and renovation of existing agency buildings and the design of new agency buildings" (Sec 3 (h)(vii)). EO 13693 builds on the efforts of EO 13653, Preparing the United States for the Impacts of Climate Change (White House 2013), which outlines priority elements for Agency Adaptation Plans (Sec 5).

DoD recognizes the need for a strategic approach to the challenges posed by global climate change, including potential impacts to missions, built infrastructure, and natural resources on DoD installations. Executive Orders, the Council on Environmental Quality (CEQ), and the Climate Change Adaptation Task Force, prompted DoD elements to enact climate change policy guidance. This was reflected in the 2014 Quadrennial Defense Review (QDR), which requires that climate change be taken seriously and directly considered in long-term Army planning. The QDR, the principal means by which the National Defense Strategy is translated into new policies and initiatives, states that:

The impacts of climate change may increase the frequency, scale, and complexity of future missions, including defense support to civil authorities, while at the same time undermining the capacity of our domestic installations to support training activities. Our actions to increase energy and water security, including investments in energy efficiency, new technologies, and renewable energy sources, will increase the resiliency of our installations and help mitigate these effects (p vi). (DoD 2014).

Finally, the Department will employ creative ways to address the impact of climate change, which will continue to affect the operating environment and the roles and missions that U.S. Armed Forces undertake. The Department will remain ready to operate in a changing environment amid the challenges of climate change and environmental damage. We have increased our preparedness for the consequences of environmental damage and continue to seek to mitigate these risks while taking advantage of opportunities. The Department's operational 
readiness hinges on unimpeded access to land, air, and sea training and test space. Consequently, we will complete a comprehensive assessment of all installations to assess the potential impacts of climate change on our missions and operational resiliency, and develop and implement plans to adapt as required (p 25). (DoD 2014).

To address the QDR, the DoD Strategic Sustainability Performance Plan (DoD 2016) defined the need to integrate climate change considerations into existing processes using robust decision-making approaches based on the best available science (Goal 4). In the DoD Climate Change Adaptation Roadmap (DoD 2012), the Army recognized that climate change interacts with stressors that it already considers and manages. In the 2013 Report to Congress on Sustainable Ranges (DoD 2013), the Army reported progress toward fulfilling this policy. The Army's approach is to integrate climate change issues into existing processes instead of considering it as a separate decision-making process. DoD intends to fully integrate climate change considerations into its extant policies, planning, practices, and programs.

This requirement was described in Secretary of Defense (SECDEF) Memo, "Actions Required to Support Defense Mission Readiness in a Changing Climate" (OSD 2013). That memorandum referred to DoD's deep experience in planning for uncertain futures, and directed the DoD Senior Sustainability Council (SSC) to establish policies and guidance for conducting consistent climate-change vulnerability assessments across DoD components. The President's climate action plan (White House 2013) re-emphasized the development of tools for more effective climate-relevant decision making. Most recently, DoD Directive 4712.21, Climate Change Adaptation and Resilience, reiterated DoD's requirement to ensure that the effects of a changing climate on DoD mission execution will be identified and addressed (DoD 2016).

The Office of the Assistant Secretary of the Army for Installations, Energy, and Environment (OASA[IE\&E]) has the lead responsibility for integrating climate change into Army planning processes. Installation 2025 (OASA[IE\&E] 2016) articulated the strategic guidance that OASA(IE\&E) established to bring climate change adaptation to fruition (Objective 2.4.3). In forming this strategy ASA(IE\&E) tasked ERDC, in FY12, to develop an adaptation planning framework that is consistent with CEQ and goals of the DoD Climate Change Adaptation Roadmap to integrate climate change 
planning in existing Army installation planning processes. This effort considered five major Army installation planning processes including:

- Installation Strategic Plan

- Installation Master Plan

- Installation Range Complex Master Plan

- Installation Integrated Natural Resource Management Plan

- Installation Critical Infrastructure Risk Management Plan.

This effort did not address Army enterprise planning processes including Base Realignment and Closure (BRAC), stationing decisions, acquisition, and deployment. The Army currently lacks approaches and tools to incorporate climate change into enterprise-wide decision processes, in part, because every location is unique. A recent Government Accountability Office (GAO) report chronicled how climate change is affecting 15 military installations in the United States, from the tundra to the coast to the desert. (GAO 2014) The report found that all DoD installations are vulnerable to climate change.

In some cases, the results were dramatic and visible, particularly in the Arctic, where the effects of climate change are magnified. A rise in temperatures, which has occurred at twice the rate as the rest of the globe, has thawed permafrost. That has literally opened holes in the ground in areas once typically used to train troops in conducting air drop and parachute drills. At a radar station along the Alaskan coast, the coastline has receded by $40 \mathrm{ft}$, resulting from a combination of melting permafrost, the disappearance of sea ice, and rising oceans. That, in turn, has destroyed parts of roads and runways, reducing the accessibility of the station.

Other extreme weather events, while not directly tied to climate change, also indicate expected impacts and trends. At Fort Irwin, which is located in the Mojave Desert, a heavy downpour in August 2013 dumped a year's worth of rain in 80 minutes, causing $\$ 64$ million in damage. Every region of the United States has seen increasing heavy downpours since the 1950s, a trend that is expected to continue.

Sea level rise also has the Norfolk Naval Shipyard considering how to keep its dry docks dry. Since 1930, the region has experienced an ocean rise of about 15 in., double the global average, resulting from a combination of sinking land and rising waters. That rise has increased the odds of storm surge reaching the docks where ships and submarines need to be kept dry 
for repairs or modifications. Any flooding could set back those repairs weeks or months such that the base administration must consider whether to build a new sea wall to keep storm water out.

While some actions are underway, planning for climate change impacts is still fraught with impediments. Figure 7, for example, shows a lakebed used as an emergency runway at Edwards Air Force base that was inundated by floods and did not dry out completely for 8 months. DoD is conducting a review of all its facilities to identify vulnerabilities starting with more than 700 coastal installations. However, there is no plan or milestones in place to ensure that the review gets finished in a timely manner. Furthermore, once the vulnerabilities are identified, there is no easy way to request funds for projects that would help reduce the risks posed by climate change or a centralized place to find out about local climate risks. Installation planners need more granular information. It is not enough to know that hurricanes are likely to increase intensity; planners want to know if they need to build roofs to withstand $100 \mathrm{mph}$ winds or $120 \mathrm{mph}$ winds.

Figure 7. A lakebed used as an emergency runway at Edwards Air Force base inundated by floods did not dry out completely for 8 months.

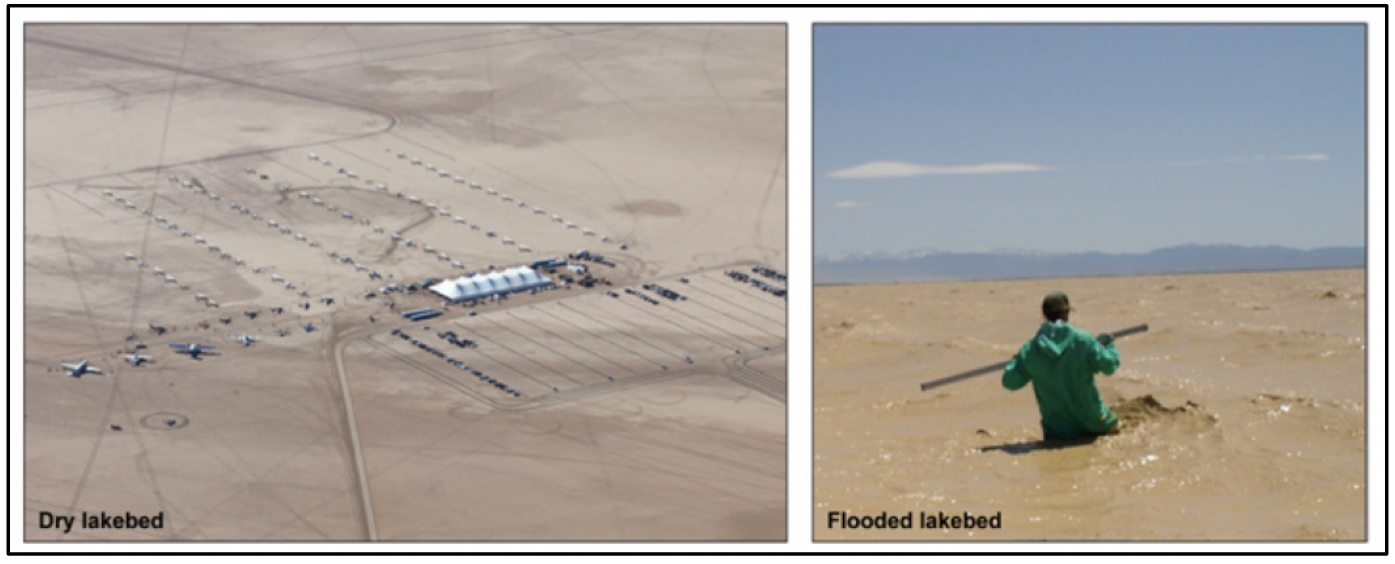

Source: U.S. Air Force

Another obstacle to overcoming climate planning challenges is the infrastructure funding process itself. Installations have to submit requests for projects that include justifications for why the projects should be funded. But DoD currently does not consider climate adaptation explicitly in its current project review process; this gives installation planners little incentive to include these types of projects in their funding requests.

Unless Army has the ability to assess and incorporate changing future conditions into Army planning scenarios, mission success as well as the long-term 
sustainability of the Army enterprise could be compromised. Currently, decision processes supporting enterprise planning assume that current environmental conditions will be static and persist as such into the future. Therefore, installation metrics used in long-term enterprise planning (e.g., BRAC, stationing, and land set-asides) are fixed values across the planning horizon. The various metrics used were created to collectively represent the capabilities, value, and costs incurred by installations meeting mission requirements. At this time, the Army has developed strategy and frameworks recognizing where climate change should be incorporated into plans. The Army does not have an objective, repeatable, time relevant, and cost appropriate approach to quantify how these metrics might change as a consequence of climate-related dynamics. That assessment remains site specific.

Changing climate will begin to affect (and in some cases is already affecting) urban development, water resources, and habitat for threatened and endangered species - all factors that are relevant to a military installation's long-term viability for mission success and conceptually related to current decision metrics. Army relevant models for various natural and built systems exist, but do not account for cause-effect relationships associated with climate change (from short to long term).

\subsection{Takeaways}

This discussion of the challenges facing the Nation's infrastructure highlights the following areas of consideration:

- Climate change impacts infrastructure assets. What are those impacts? Does the geographical location of assets make them more or less vulnerable? Does this put future operations at risk? These questions remain difficult to answer. Frameworks are beginning to emerge that tackle these concerns.

- There are deficiencies in nationwide data regarding infrastructure condition and performance remain.

- Executive Orders and other mandates encourage actions to prepare for and adjust to new conditions (e.g., climate change), and thereby reducing harm or taking advantage of new opportunities. Yet, guidance on how to achieve this lags.

- How individuals will respond to climate change is still unknown. Agencies are currently focused on building adaptive capacity and resilience, but how will people move and how will urbanization change? It may be 
necessary to rethink the relationship between drivers. The DOT identifies congestion as a more significant issue than climate change since it expects climate change to shift congestion intensities to new geographic locations and systems.

- The impact of climate change to the transportation system can be mitigated through rerouting, mode change, and a wide range of adaptive actions and technologies. The concern is that no one is predicting these problems or planning for future requirements.

- The U.S. government recognizes climate change as an issue, but has never addressed it with regards to enterprise planning processes including BRAC and deployment activities. Climate impacts are visible, but planning for those impacts is still a challenge.

- Weather is inherently intertwined with the ability of the Army to successfully complete required training and testing missions, and to operate and maintain both built and natural infrastructure. 


\section{Army Stationing Analysis}

\subsection{Background}

Due to changing conditions and challenges around the world, changing political situations, and evolving technologies and tactics, the requirements for keeping the Army mission-ready are always adapting. One consequence is that the Army often finds itself with excess, unwanted, or unneeded facilities. In the 1950s, DoD began downsizing its inventory of land and infrastructure, and through the 1960s, DoD was free to make its own divestment decisions. In the 1970 s and early 1980 os closures were largely halted, which prevented loss of jobs in areas that might otherwise have been closed. With the pressure of pent-up needs to realign installations and bases in the U.S, Congress passed PL 100-526 (BRAC 1988), which authorized "BRAC 88." Congress then added language to Section 29 of the "National Defense $\mathrm{Au}$ thorization Act Year 1991" that authorized future rounds of BRAC. Additional rounds were conducted in 1991, 1993, 1995, and 2005.

BRAC 2005 was the first round in 10 years and the most current to date. Unlike previous BRAC rounds, the military structure was not in a drawdown mode and the Nation and military were in a post-9/11 environment. Military transformation was a major emphasis. BRAC 2005 analyses were to be considered with respect to a 20-year time horizon that required consideration of a 20-year Net Present Value (NPV) cost horizon. Another major change was that, in addition to the three military departments conducting analyses for input into the process, seven Joint Cross-Service Groups (JCSG) were allowed to have direct input for the first time. The Center for Army Analysis (CAA) was tasked to support the BRAC analyses. Eight criteria were established for conducting the BRAC 2005 analyses:

- Criterion 1 - The current and future mission capabilities and the impact on operational readiness of the total force of the Department of Defense, including the impact on joint warfighting, training, and readiness.

- Criterion 2 - The availability and condition of land, facilities and associated airspace (including training areas suitable for maneuver by ground, naval, or air forces throughout a diversity of climate and terrain areas and staging areas for the use of the Armed Forces in homeland defense missions) at both existing and potential receiving locations. 
- Criterion 3 - The ability to accommodate contingency, mobilization, and future total force requirements at both existing and potential receiving locations to support operations and training.

- Criterion 4 - The cost of operations and the manpower implications.

- Criterion 5 - The extent and timing of potential costs and savings, including the number of years, beginning with the date of completion of the closure or realignment, for the savings to exceed the costs (COBRA).

- Criterion 6 - The economic impact on existing communities in the vicinity of military installations.

- Criterion 7-The ability of the infrastructure of both the existing and potential receiving communities to support forces, missions, and personnel.

- Criterion 8 - The environmental impact, including the impact of costs related to potential environmental restoration, waste management, and environmental compliance activities.

The first four criteria were considered as Military Value Analysis (MVA) criteria; the last four as "Other." The installation ranking and scores developed through the MVA process were combined with additional installation quantitative and qualitative data as inputs to the Optimal Stationing of Army Forces (OSAF) model that optimally allocated military units to installations, resulting in potential courses of action (COAs). These were evaluated using the Cost of Base Realignment Actions (COBRA) calculations that provided the final data points that allowed final COA recommendations. Figure 8 illustrates the CAA method.

Figure 8. CAA methods.

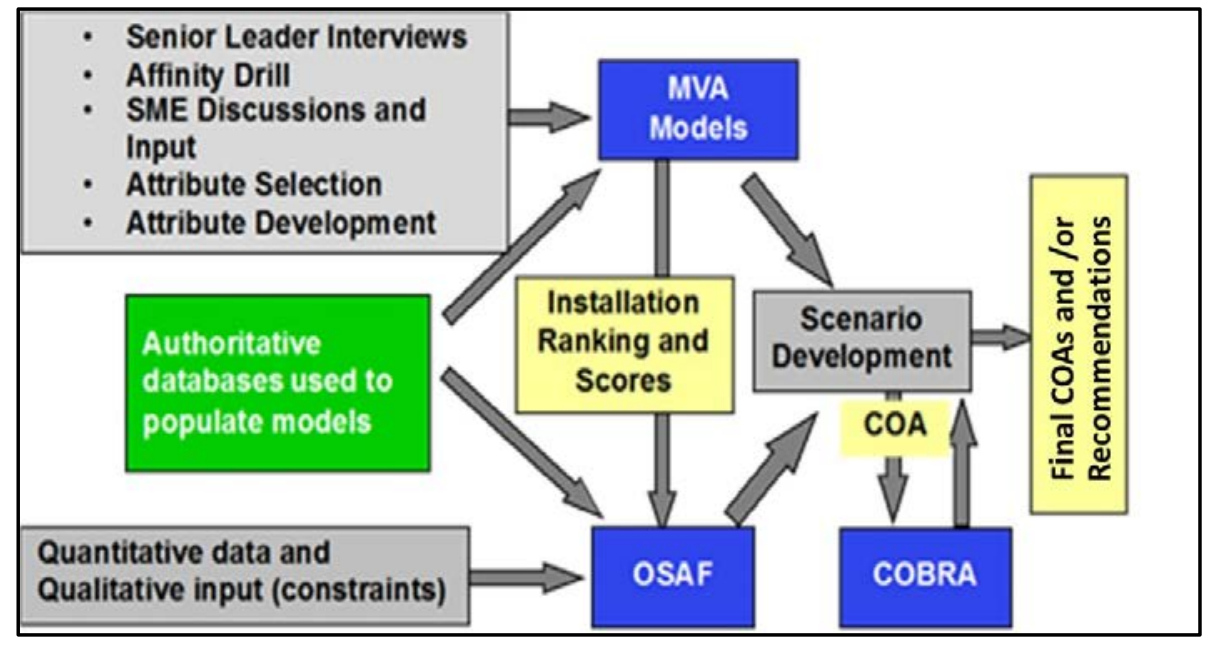




\subsection{Military value analysis}

CAA uses the MVA process for stationing and realignment analyses and adapts the process to each specific application. It employs a Multi-Objective Decision Analysis (MODA) that involves quantifying qualitative data/information. The understandings and knowledge of senior leaders and subject matter experts are gathered to identify the appropriate considerations, to establish qualitative values for those considerations across installations, and to establish quantification of those values to support combination and integration. For each MVA application, CAA seeks to ensure that the chosen installation attributes meet the SMART criteria, i.e., to be:

- Specific - clear and focused to avoid misinterpretation; assumptions and definitions should be easily interpreted or explained.

- Measurable - can be quantified and compared to other data; should allow for meaningful statistical analysis (avoid binary "yes/no" measures - those become screening criteria).

- Attainable - achievable, reasonable, and credible under conditions expected.

- Realistic - fits into the models and is cost-effective.

- Timely - achievable within the time frame given.

The attribute metrics must be combined, resulting in an overall score for each installation. Hence, each attribute must be scaled in some manner and then properly weighted for combination with other attributes. For BRAC 2005, 40 attributes were chosen to represent the value of installations. Each attribute was identified as having one of three levels of operational support and one of three primary levels of "ability to change":

(1) mission (very difficult to change), (2) mission support (difficult to change), and (3) mission enablers (changeable with Army dollars). Finally, each was associated with an importance weight on a scale of 1 to 100. The current CAA MVA methods employ the following seven steps:

1. Review the most recent application of MVA.

2. Add/delete/update attributes and value conversion curves to reflect the current requirement.

3. Modify weighting scheme, if needed, using subject matter expert (SME) input.

4. Receive list of installations for consideration.

5. Collect installation data from designated organizations.

6. Calculate values for installation alternatives and run sensitivity analyses.

7. Work with the customer (G-3) to prepare recommendations for Army senior leadership. 
The MVA methods first developed for BRAC 2005 were vetted, validated, audited, and approved by senior Army and DoD leadership, and has since been applied to many stationing analyses. A recent analysis reduced the important attributes down to a total of 16 , making the process efficient, while remaining effective.

\subsection{Deployment infrastructure MVA attributes}

MVA has three attributes regarding deployment infrastructure. The deployment attributes were significantly updated in 2014 under advisement of USTRANSCOM SDDC. Calculation sheets for each attribute can be found in the Appendix A. They three attributes are:

1. Air Deployment Infrastructure.

A categorical rating of the air deployment infrastructure at an installation's APOE based on runway length, maximum aircraft on ground (MOG), and hot cargo pads. Runway length captures the length of the primary runway at an installation's designated primary APOE. The MOG is the number of aircraft the APOE can accommodate for an Army air deployment and includes the parking MOG and working MOG. A hot cargo pad is an area specifically designated for the loading of explosive or hazardous cargo onto an aircraft.

2. Surface Deployment Infrastructure.

A categorical rating of the surface deployment infrastructure on an installation based on rail loading tracks, rail classification tracks, rail marshaling areas, truck loading ramps, and unit cargo staging - truck loading and truck loading areas. Rail loading tracks are defined as tangent (straight) tracks with permanent or portable end loading ramps used for loading railcars while classification tracks are for railcar storage and switching operations. Rail marshaling areas are the open areas (paved or unpaved) where unit equipment is staged before railcar loading. Truck loading ramps are permanent ramps for loading flatbed and heavy equipment transport (HET) trucks. The areas at the truck loading ramps for staging unit cargo and staging the flatbed/HET trucks during truck loading are also captured.

3. Deployment Support Infrastructure.

A categorical rating of the deployment support infrastructure on an installation based on container transfer pads, container storage, inspection lanes, vehicle scales, and vehicle inspection staging areas. A container transfer pad is the area at the installation railhead designated for staging and loading containers onto railcars while container storage is the total 
number of containers that can be stored on the installation. Vehicle inspection lanes, scales, and staging areas are the dedicated facilities for pre-deployment inspection activities.

Each attribute measures the installation's ability to pack up for movement. They do not account for movement beyond the installation fenceline. It is a snapshot of deployment capability (e.g., deployability) as a tiered ability in which " 1 " has no ability to deploy and "10" has the ability to deploy a battalion in 2 days. Assumptions are made as to equipment requirements for each tier.

\subsection{Optimal stationing of Army forces}

OSAF uses an integer-programming optimization approach to match units to installations. Loerch et al. (1996) reported an early application of this approach to the challenge of stationing across Germany. The original OSAF model was developed before the 2005 BRAC to aid in stationing decisions (Dell and Tarantino 2003). Previously, an analysis model called the Base Realignment and Closure Action Scheduler (BRACAS) was developed to support the BRAC 95 analyses (Dell 1998), marking the first time (November 1994) that optimization programming was used to support base realignment. This effort had its foundation in Naval Postgraduate School (NPS) software efforts. Singleton (1991) and Tarantino (1992) developed an early stationing optimization analysis tool as Master's theses. These capabilities were developed at NPS and incorporated into the Optimally Stationing Units to Bases (OSUB) analysis software (Dell et al. 1994). OSUB used an elastic bi-criterion mixed integer-programming model that combined military value with cost objectives to assist the Army with closure and realignment. An early version of OSAF was applied to Korea (OSAFK) to optimally station 194 units across 51 installations (Gezer 2001).

OSAF was further developed at CAA for the purpose of supporting future analysis requirements (Tarantino and Connors 2001). In preparation for the development of OSAF to support BRAC 2005, Tarantino, et al. (2002) conducted a thorough literature review of the documents, policies, circulars, reports, etc. that needed to be considered to support the BRAC 2005 process. They went on to document the original OSAF implementation designed to support that BRAC.

The final version of OSAF used in BRAC 2005 was documented by Dell, Ewing, and Tarantino (2008) using an integer-programming optimization description capability called GAMS (GAMS Development Corporation) and 
the CPLEX solver, the combination of which is called GAMS/CPLEX. The input to the model takes the form of: (1) descriptions of the stationing capabilities, (2) limitations of about 70 installations grouped into five types where soldiers can be stationed, and (3) need descriptions of about 6000 units aggregated into 655 stationing packages. The goal of the optimization model is to house the stationing packages at the 70 installations in a manner that minimizes the NPV of the solution, subject to the installation capabilities and constraints. Installation capacities and considerations include:

- Building inventory, condition, and size in square feet.

- Population.

- Maneuver land and range days available.

- Housing inputs include: staffing, percent married, number of units, housing allowances, and on-base costs.

- Additional inputs include: Base Operating Support, Real Property Maintenance, moving costs and mileage, Military Construction [MIL$\mathrm{CON}]$ cost factors, and Program costs (program management, mothball, caretaker).

- Military Value Scores (from the MVA model).

OSAF post-optimization reviews consider a number of factors not specifically considered by the objective function. These include the net present value, the overall military value, the turbulence (number of units moved), strategic implications, quality of life, environment, and ease of mobilization/deployment. For BRAC 2005, application of OSAF recommended closing 13 installations that primarily house active duty soldiers, 176 Army Reserve centers, and 211 National Guard armories, and realignment of 56 active component units.

\subsection{Takeaways}

This discussion of the Army stationing analysis elicited the following observations:

- Every stationing and realignment analysis is unique due to changes in mission needs, availability of data, ability to forecast the future, and continued opportunities for improvement. Analyses have evolved in response to problems with earlier solutions.

- The current versions of MVA and OSAF rely on installation metrics that are acquired as a snapshot-in-time, with the presumption that the values will not significantly change. This approach was adequate when BRAC analyses were done every few years, as was done between 1988 and 
1995, so long as BRAC decisions used an adaptive management approach in which decisions allowed movement toward a desired future without fully committing to that future. However, it was 10 years between the last two BRAC analyses, and will be a minimum of 12 years between the most recent BRAC (2005) and the next one. With a decade or more between BRAC analyses, BRAC recommendations tend to be more far-reaching and aggressive. Therefore, they must strive to look farther into the future and with more clarity to ensure the development of wise recommendations. While the BRAC 2005 version of MVA acknowledged and considered the changing value of money over 20 years, future versions of BRAC may need to consider changing installation metrics, conditions, capabilities and costs forecasted to 30 or 40 years.

- BRAC is a complex suite of methods that must be completed in a timely manner. CAA seeks to ensure that the chosen installation attributes meet the SMART criteria.

- MVA contains three deployment attributes that feed the BRAC process. Each attribute measures an installation's ability to pack up for movement. 


\section{Conclusion}

\subsection{Does climate change pose a significant threat to future deployability?}

\section{Potentially.}

Climate change significantly impacts transportation systems. Storms are problematic for physical structures. Still, there remains an inadequacy of data and understanding to act-how will the frequency, duration, and intensity of storms change?

Despite many localized initiatives, little attention is being given to larger system issues that inform enterprise-wide deployment concerns. Technology like the models developed by USTRANSCOM mitigate regional impacts such as hazards/congestion or route closures. Installations located in climates with snow and ice, for example, opt not to pre-position rail containers on post due to the high burdens in snow and ice removal. Instead, containers are shipped on demand. These installations meet the same readiness standards as installations located in warm climates where containers are prepositioned on post. The resulting question is whether all impacts can be mitigated and whether these adaption practices become a cost burden to the Army. Further analysis is needed to make that determination.

\subsection{Should climate change influence stationing decisions regarding deployment?}

\section{Not at this time.}

Climate change certainly needs to be viewed as another risk to Army readiness and its ability to deploy and operate. Despite the current ability to qualitatively estimate those risks, too many unknowns remain to successfully incorporate quantifiable metrics on deployment as a consideration for a potential BRAC 2017. However, it should remain a possible consideration for future BRAC analyses. The evolving nature of the BRAC process is its biggest strength. For now, science has the most understanding of climate change impacts with regard to other missions such as the protection of the natural environment, building construction, and the supply of water and energy. It makes sense to begin with these, and then to evolve to readiness. 
Furthermore, deployment requires support and integration from a broad spectrum of agencies. Input from all of these stakeholders needs to be coordinated to ensure a successful and accurate account of climate change impacts on military readiness. 


\section{Appendix A: MVA Attributes}

This appendix contains the latest available versions of the three MVA attributes described in this report:

1. Air Deployment Infrastructure (12 May 2014)

2. Surface Deployment Infrastructure (14 May 2014)

3. Deployment Support Infrastructure (14 May 2014). 


\section{A.1 Air deployment infrastructure (as of 12 May 2014)}

1. Definition: A categorical rating of the air deployment infrastructure at an installation's APOE based on runway length, maximum aircraft on ground (MOG), and hot cargo pads. Runway length captures the length of the primary runway at an installation's designated primary APOE. The MOG is the number of aircraft that the APOE can accommodate for an Army air deployment and includes the parking MOG and working MOG. A hot cargo pad is an area specifically designated for the loading of explosive or hazardous cargo onto an aircraft.

2. Purpose: Shows the ability of an installation's APOE to handle air deployments.

3. Source/POC: G-4 DALO-FPM*

4. Methods:

a. Data is collected with on-site assessments and from installation staff.

b. Determine the length in linear feet of the APOE runway.

c. Determine the maximum number of aircraft on ground at the installation's APOE.

d. Determine the number of hot cargo pads at the installation's APOE.

e. Using Table A-1, determine a score for each metric for the installation and sum the individual scores for a total air deployment score for the installation.

\section{Equation:}

Air deployment score $=($ APOE runway length score $)+($ MOG score $)$ + (hot cargo pads score)

\section{Model Requirements:}

a. Model Inputs:

(1) The installation's APOE runway length, MOG, and hot cargo pads are the model's primary inputs.

(2) The maximum value of 30 will be given to the longest APOE runway (10,000 or more), the most MOG ( 9 or more), and the most hot cargo pads (three or more).

(3) The installation receives no value if it has none of the deployment infrastructure used in the model.

(4) Table A-1 is used to determine the scores for each metric. 
Table A-1. Air deployment scores for installation metrics.

\begin{tabular}{|c|c|c|c|}
\hline Score & $\begin{array}{c}\text { APOE } \\
\text { Runway } \\
\text { Length }\end{array}$ & $\begin{array}{c}\text { Max } \\
\text { Aircraft } \\
\text { on } \\
\text { Ground } \\
\text { (MOG) }\end{array}$ & $\begin{array}{c}\text { Hot } \\
\text { Cargo } \\
\text { Pads }\end{array}$ \\
\hline Ten & 10,000 & 9 & 3 \\
\hline Nine & 9,000 & 8 & - \\
\hline Eight & 8,000 & 7 & 2 \\
\hline Seven & 7,000 & 6 & - \\
\hline Six & 6,000 & 5 & - \\
\hline Five & 5,000 & - & - \\
\hline Four & 4,000 & 4 & 1 \\
\hline Three & 3,000 & 3 & - \\
\hline Two & 2,000 & 2 & - \\
\hline One & 1,000 & 1 & - \\
\hline Zero & 0 & 0 & 0 \\
\hline
\end{tabular}

b. Value Function:

(1) The value function converts the score/category into military value.

(2) The value function is linear increasing.

(3) A maximum value of 10 is given to an installation with a score of 30

(Figure A-1).

(4) A minimum value of $\mathrm{o}$ is given to an installation with a score of $\mathrm{o.}$

Figure A-1. Air deployment infrastructure score.

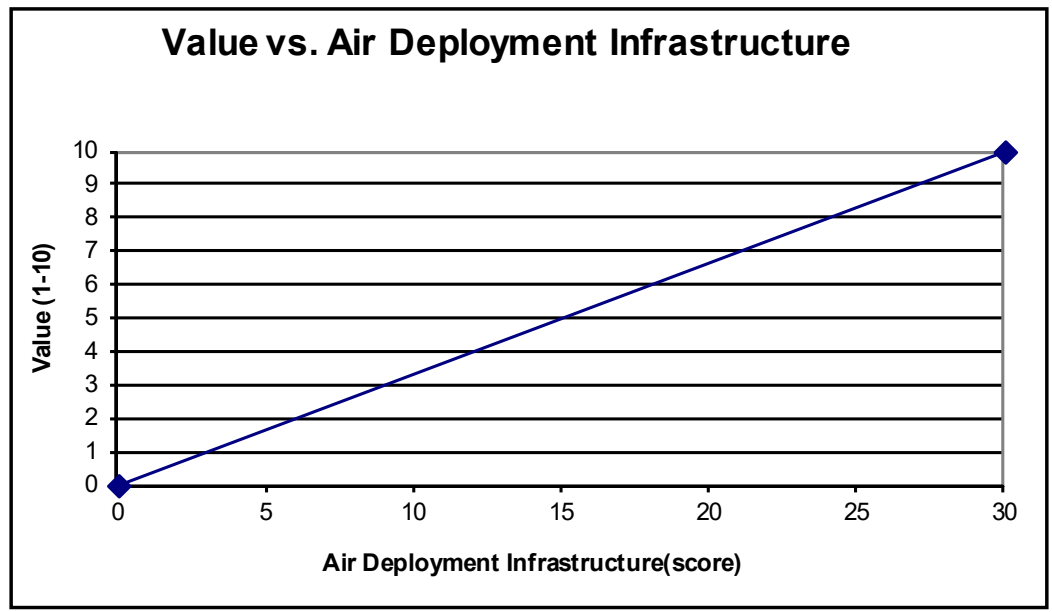




\section{A.2 Surface deployment infrastructure (as of 14 May 2014}

1. Definition: A categorical rating of the surface deployment infrastructure on an installation based on rail loading tracks, rail classification tracks, rail marshaling areas, truck loading ramps, and unit cargo staging - truck loading and truck loading areas. Rail loading tracks are defined as tangent (straight) tracks with permanent or portable end loading ramps used for loading railcars while classification tracks are for railcar storage and switching operations. Rail marshaling areas are the open areas (paved or unpaved) where unit equipment is staged before railcar loading. Truck loading ramps are permanent ramps for loading flatbed and heavy equipment transport (HET) trucks. The areas at the truck loading ramps for staging unit cargo and staging the flatbed/HET trucks during truck loading are also captured.

2. Purpose: Shows the ability of an installation to handle surface deployments over rail or road.

3. Source/POC: G-4 DALO-FPM

4. Methods:

a. Data is collected with on-site assessments and from installation staff.

b. Determine the total linear feet of rail loading track.

c. Determine the total linear feet of rail classification/storage track.

d. Determine the area of the rail marshaling area in square feet.

e. Determine the number of truck loading ramps.

f. Determine the size of the unit cargo staging area at the truck loading ramps in square feet.

g. Determine the size of the truck loading area in square feet.

h. Using the table below, determine a score for each metric for the installation and sum the individual scores for a total surface deployment score for the installation.

\section{Equation:}

Surface deployment score $=($ rail loading track score $)+($ rail classification track score $)$ + (rail marshaling area score) + (truck loading ramp score) + (unit cargo staging - truck loading score) + (truck loading area score)

\section{Model Requirements:}

a. Model Inputs:

(1) The installation's rail loading tracks, rail classification tracks, rail marshaling areas, truck loading ramps, and unit cargo staging - truck loading and truck loading areas are the model's primary inputs.

(2) The maximum value of 60 will be given to the installations with the most rail loading track $(12,667 \mathrm{ft}$ or over), the most rail classification track (12,000 ft or over), the largest rail marshaling area 
(296,800 sq ft or more), the most truck loading ramps (four or more), the largest unit cargo staging - truck loading (40,000 sq ft or more), and the largest truck loading area (20,000 sq $\mathrm{ft}$ or more).

(3) The installation receives no value if it has none of the deployment infrastructure used in the model.

(4) Table A-2 is used to determine the scores for each metric; the installation's tier determines the column that is used for each metric.

Table A-2. Surface deployment scores for installation metrics.

\begin{tabular}{|c|l|c|c|l|l|l|}
\hline Score & $\begin{array}{l}\text { Rail } \\
\text { Loading } \\
\text { Track } \\
\text { (LF) }\end{array}$ & $\begin{array}{c}\text { Rail } \\
\text { Classification } \\
\text { Track (LF) }\end{array}$ & $\begin{array}{l}\text { Rail } \\
\text { Marshaling } \\
\text { Area (SF) }\end{array}$ & $\begin{array}{l}\text { Truck } \\
\text { Loading } \\
\text { Ramps } \\
(\#)\end{array}$ & $\begin{array}{l}\text { Unit } \\
\text { Cargo } \\
\text { Staging } \\
\text { Truck } \\
\text { Loading }\end{array}$ & $\begin{array}{l}\text { Truck } \\
\text { Loading } \\
\text { Area (SF) }\end{array}$ \\
\hline Ten & 12,667 & 12,000 & 296,800 & 4 & 40,000 & 20,000 \\
\hline Nine & 11,400 & 10,800 & 267,120 & - & 36,000 & 18,000 \\
\hline Eight & 10,134 & 9,600 & 237,440 & 3 & 32,000 & 16,000 \\
\hline Seven & 8,867 & 8,400 & 207,760 & - & 28,000 & 14,000 \\
\hline Six & 7,600 & 7,200 & 178,080 & 2 & 24,000 & 12,000 \\
\hline Five & 6,334 & 6,000 & 148,400 & - & 20,000 & 10,000 \\
\hline Four & 5,067 & 4,800 & 118,720 & - & 16,000 & 8,000 \\
\hline Three & 3,800 & 3,600 & 89,040 & 1 & 12,000 & 6,000 \\
\hline Two & 2,533 & 2,400 & 59,360 & - & 8,000 & 4,000 \\
\hline One & 1,267 & 1,200 & 29,680 & - & 4,000 & 2,000 \\
\hline Zero & 0 & 0 & 0 & 0 & 0 & 0 \\
\hline
\end{tabular}

b. Value Function:

(1) The value function converts the score/category into military value.

(2) The value function is linear increasing.

(3) A maximum value of 10 is given to an installation with a score of 60 (Figure A-2).

(4) A minimum value of $o$ is given to an installation with a score of $O$.

Figure A-2. Surface deployment infrastructure score.

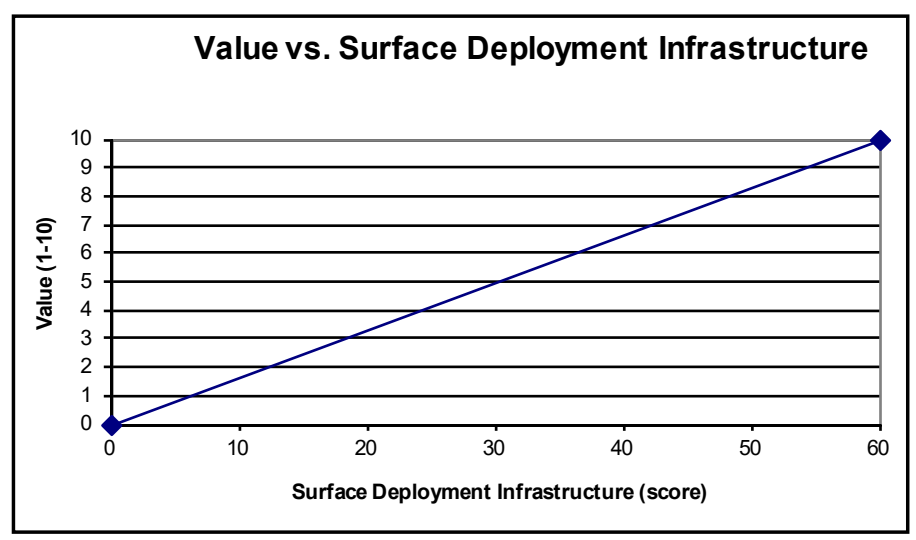




\section{A.3 Deployment support infrastructure (as of 14 May 2014)}

1. Definition: A categorical rating of the deployment support infrastructure on an installation based on container transfer pads, container storage, inspection lanes, vehicle scales, and vehicle inspection staging areas. A container transfer pad is the area at the installation railhead designated for staging and loading containers onto railcars while container storage is the total number of containers that can be stored on the installation. Vehicle inspection lanes, scales, and staging area are the dedicated facilities for pre-deployment inspection activities.

2. Purpose: Shows the ability of an installation to support deployments, specifically through container deployment and pre-deployment inspection of equipment.

3. Source/POC: G-4 DALO-FPM

4. Methods:

a. Data is collected with on-site assessments and from installation staff.

b. Determine the area of the container transfer pad in square feet.

c. Determine the container storage on the installation in 20-ft equivalent units (TEUs).

d. Determine the number of vehicle inspection lanes.

e. Determine the number of vehicle scales.

f. Determine the area of the vehicle inspection staging area in square feet.

g. Using the table below, determine a score for each metric for the installation and sum the individual scores for a total air deployment score for the installation.

5. Equation: Deployment support score $=($ container transfer pad score $)+($ container storage score $)+($ inspection lane score $)+($ vehicle scale score $)+($ vehicle inspection staging score)

6. Model Requirements:

a. Model Inputs:

(1) The installation's container transfer pads, container storage, inspection lanes, vehicle scales, and vehicle inspection staging areas are the model's primary inputs.

(2) The maximum value of 50 will be given to the installations with largest container transfer pad ( $53,558 \mathrm{sq} \mathrm{ft}$ or more), the most container storage (greater than or equal to requirement), the most inspection lanes (four or more), the most vehicle scales (four or more), and the largest vehicle inspection staging area (100,000 sq ft or more).

(3) The installation receives no value if it has none of the deployment infrastructure used in the model. 
(4) The table below is used to determine the scores for each metric.

Table A-3. Container transfer deployment scores for installation metrics.

\begin{tabular}{|c|c|c|c|c|c||}
\hline Score & $\begin{array}{c}\text { Container } \\
\text { Transfer } \\
\text { Pad (SF) }\end{array}$ & $\begin{array}{c}\text { Container } \\
\text { Storage } \\
\text { (TEUs) }\end{array}$ & $\begin{array}{l}\text { Inspection } \\
\text { Lanes (\#) }\end{array}$ & $\begin{array}{l}\text { Vehicle } \\
\text { Scales } \\
\text { (\#) }\end{array}$ & $\begin{array}{l}\text { Vehicle } \\
\text { Inspection } \\
\text { Staging } \\
\text { Area (SF) }\end{array}$ \\
\hline Ten & 53,558 & $\geq$ Req't & 4 & 4 & 100,000 \\
\hline Nine & 48,202 & $\geq 90 \%$ Req't & - & - & 90,000 \\
\hline Eight & 42,846 & $\geq 80 \%$ Req't & 3 & 3 & 80,000 \\
\hline Seven & 37,491 & $\geq 70 \%$ Req't & - & - & 70,000 \\
\hline Six & 32,135 & $\geq 60 \%$ Req't & 2 & 2 & 60,000 \\
\hline Five & 26,779 & $\geq 50 \%$ Req't & - & - & 50,000 \\
\hline Four & 21,423 & $\geq 40 \%$ Req't & - & - & 40,000 \\
\hline Three & 16,067 & $\geq 30 \%$ Req't & 1 & 1 & 30,000 \\
\hline Two & 10,712 & $\geq 20 \%$ Req't & - & - & 20,000 \\
\hline One & 5,356 & $\geq 10 \%$ Req't & - & - & 10,000 \\
\hline Zero & 0 & $<10 \%$ Req't & 0 & 0 & 0 \\
\hline \hline
\end{tabular}

b. Value Function:

(1) The value function converts the score/category into military value.

(2) The value function is linear increasing.

(3) A maximum value of 10 is given to an installation with a score of 50.

(4) A minimum value of $o$ is given to an installation with a score of $o$.

Figure A-3. Container transfer deployment infrastructure score.

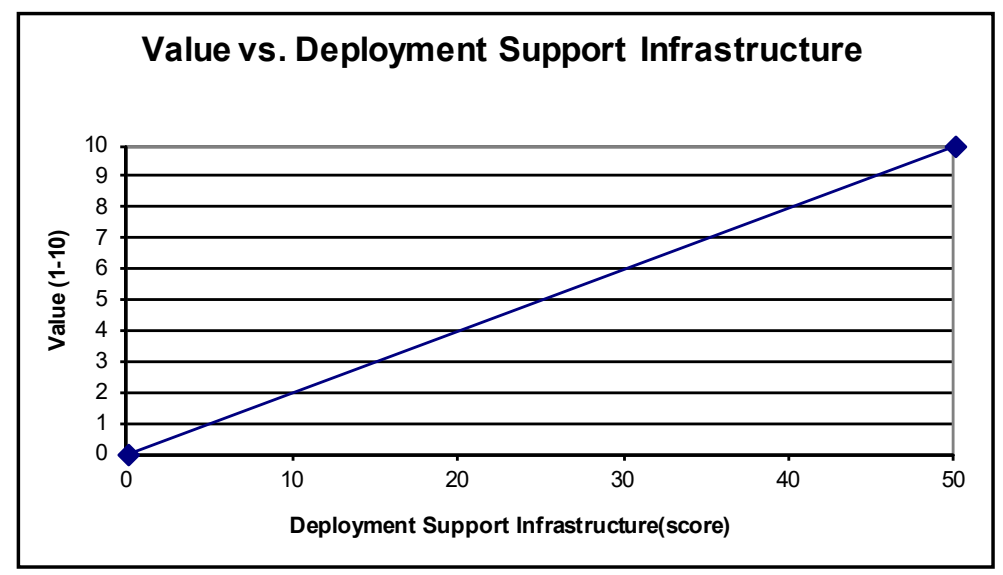




\section{Acronyms and Abbreviations}

\begin{tabular}{|c|c|}
\hline $\begin{array}{l}\text { Term } \\
\text { AAF }\end{array}$ & $\begin{array}{l}\text { Definition } \\
\text { Army Airfield }\end{array}$ \\
\hline AFB & Air Force Base \\
\hline AMC & U.S. Army Materiel Command \\
\hline AMP & Analysis of Mobility Platform \\
\hline AMP-PAT & Analysis of Mobility Platform Port Analysis Tools \\
\hline ANSI & American National Standards Institute \\
\hline APOE & Aerial Port of Embarkation \\
\hline ASCE & American Society of Civil Engineers \\
\hline BRAC & Base Realignment and Closure \\
\hline BRACAS & Base Realignment and Closure Action Scheduler \\
\hline CAA & Center for Army Analysis \\
\hline CASCOM & US Army Combined Arms Support Command \\
\hline CEERD & U.S. Army Corps of Engineers, Engineer Research and Development Center \\
\hline CEQ & Council on Environmental Quality \\
\hline CERL & Construction Engineering Research Laboratory \\
\hline CJCS & Chairman of the Joint Chiefs of Staff \\
\hline $\mathrm{COA}$ & Course of Action \\
\hline COBRA & Cost of Base Realignment Actions \\
\hline CONUS & Continental United States \\
\hline DoD & U.S. Department of Defense \\
\hline DOT & Department of Transportation \\
\hline DPMO & Deployment Process Modernization Office \\
\hline EO & Executive Order \\
\hline ERDC & U.S. Army Engineer Research and Development Center \\
\hline ERDC-CERL & $\begin{array}{l}\text { Engineer Research and Development Center, Construction Engineering } \\
\text { Research Laboratory }\end{array}$ \\
\hline FAA & Federal Aviation Administration \\
\hline FHWA & Federal Highway Administration \\
\hline FORSCOM & U.S. Army Forces Command \\
\hline FRA & Federal Railroad Administration \\
\hline GAMS & General Algebraic Modeling System \\
\hline GAO & Government Accountability Office \\
\hline GIS & Geographic Information System \\
\hline GPS & Global Positioning System \\
\hline HET & Heavy Equipment Transport \\
\hline IMCOM & U.S. Army Installation Management Command \\
\hline IRRIS & Intelligent Road/Rail Information Server \\
\hline IWR & Institute for Water Resources \\
\hline JAMCE & Joint Mobility Closure Estimator \\
\hline
\end{tabular}




\begin{tabular}{|c|c|}
\hline $\begin{array}{l}\text { Term } \\
\text { JCSG }\end{array}$ & $\begin{array}{l}\text { Definition } \\
\text { Joint Cross-Service Group }\end{array}$ \\
\hline LBS & Location-Based Service \\
\hline MCAS & Marine Corps Air Station \\
\hline MILCON & Military Construction \\
\hline MODA & Multi-Objective Decision Analysis \\
\hline MOG & Maximum aircraft On Ground \\
\hline MSC & Military Sealift Command \\
\hline MTMC & Military Traffic Management Command \\
\hline MVA & Military Value Analysis \\
\hline NCA & National Climate Assessment \\
\hline NPS & Naval Postgraduate School \\
\hline NPV & Net Present Value \\
\hline NSN & National Supply Number \\
\hline OASA(IE\&E) & $\begin{array}{l}\text { Office of the Assistant Secretary of the Army for Installations, Energy, and } \\
\text { Environment }\end{array}$ \\
\hline OMB & Office of Management and Budget \\
\hline OSAF & Optimal Stationing of Army Forces \\
\hline OSAFK & Optimal Stationing of Army Forces, Korea \\
\hline OSD & Office of the Secretary of Defense \\
\hline OSUB & Optimally Stationing Units to Bases \\
\hline PL & Public Law \\
\hline PO & Post Office \\
\hline POC & Point of Contact \\
\hline POE & price-of-electricity \\
\hline PPP & Power Projection Platform \\
\hline QDR & Quadrennial Defense Review \\
\hline RCAT & Rapid Course of Action Analysis Tool \\
\hline REDI & Rapid Expeditionary Deployment Initiative \\
\hline RND & Railroads for National Defense Program \\
\hline SAR & Same As Report \\
\hline SDDC & Surface Deployment and Distribution Command \\
\hline SDDCTEA & $\begin{array}{l}\text { Surface Deployment and Distribution Command Transportation } \\
\text { Engineering Agency }\end{array}$ \\
\hline SECDEF & Secretary of Defense \\
\hline SF & Standard Form \\
\hline SMART & Sustainable, Mobile, Alternative and Renewable Technologies \\
\hline SME & Subject Matter Expert \\
\hline SPOE & Sea Port of Embarkation \\
\hline SSC & Senior Sustainability Council \\
\hline SSPP & Strategic Sustainability Performance Plan \\
\hline STRACNET & Strategic Rail Corridor Network \\
\hline STRAHNET & Strategic Highway Network \\
\hline
\end{tabular}




$\begin{array}{ll}\text { Term } & \text { Definition } \\ \text { TARGET } & \text { Transportability Analysis Report Generator } \\ \text { TEA } & \text { Transportation Engineering Agency } \\ \text { TERM } & \text { Transit Economic Requirements Model } \\ \text { TEU } & \text { Twenty-foot Equivalent Unit } \\ \text { TR } & \text { Technical Report } \\ \text { TRADOC } & \text { U.S. Army Training and Doctrine Command } \\ \text { TTI } & \text { Texas A\&M Transportation Institute } \\ \text { U.S. } & \text { United States } \\ \text { USACE } & \text { U.S. Army Corps of Engineers } \\ \text { USASOC } & \text { U.S. Army Special Operations Command } \\ \text { USTRANSCOM } & \text { U.S. Transportation Command } \\ \text { VAST } & \text { (Federal Highway Administration) Vulnerability Assessment Scoring Tool }\end{array}$




\section{References}

American Society of Civil Engineers (ASCE). 2009. 2009 Report Card for America's Infrastructure. Website. Reston, VA: ASCE, http://www.infrastructurereportcard.org/2009/

BRAC 88. Public Law (PL) No. 100-526. 1988. 102 STAT. 2623.

Chairman of the Joint Chiefs of Staff (CJCS). 2013. Deployment and Redeployment Operations. Joint Publication 3-35. Washington, DC: CJCS, http://www.dtic.mil/doctrine/new_pubs/ip3_35.pdf

Dell, R. 1998. Optimizing Army base realignment and closure. Interfaces 28(6):1-18

Dell, R. F., and W. J. Tarantino. 2003. How Optimization Supports Army Base Closure and Realignment. NPS-OR-03-003-PR. Monterey, CA: Naval Postgraduate School.

Dell, R. F., C. Fletcher, S. H. Parry, and R. E. Rosenthal. 1994. Modeling Army Maneuver and Training Base Realignment and Closure. Master's Thesis. ADA278704. NPS-OR-94-002. Monterey, CA: Naval Postgraduate School.

Dell, R. F., P. L. Ewing, and W. J. Tarantino. 2008. Optimally stationing Army forces. Interfaces. 38(6):421-435.

Deployment Process Modernization Office (DPMO). 2016. REDI Toolbox. Website. Fort Lee, VA: U.S. Army Combined Arms Support Command (CASCOM), https://www.us.army.mil/suite/page/689011

Federal Highway Administration (FHWA). 2014. Assessing Transportation Vulnerability to Climate Change: Synthesis of Lessons Learned and Methods Applied. FHWAHEP-15-007. Washington, DC: FHWA, http://www.fhwa.dot.gov/environment/climate_change/adaptation/ongoing_and_current_rese arch/gulf_coast_study/phase2_task6/fhwahep15007.pdf

2005. Coordinating Military Deployments on Roads and Highways: A Guide for State and Local Agencies. Washington, DC: FWHA, Federal Transit

Administration, http://ops.fhwa.dot.gov/publications/fhwahop05029/fhwahop05029.pdf

- 2013. Status of the Nation's Highways, Bridges, and Transit: Conditions \& Performance. Washington, DC: FWHA, Federal Transit Administration, https://www.fhwa.dot.gov/policy/2013cpr/

Federal Railroad Administration (FRA). 2015. Needs Assessment: Railroad Test Track Siding Operations for High Speed Testing. DOT/FRA/ORD-15/24. Washington, DC: Office of Research, Development, and Technology.

2009. Preliminary National Rail Plan. Washington, DC: FRA, https://www.fra.dot.gov/eLib/details/L02695\#p2_z50_gD_y2009 
Gentry, Jennifer, Kent Duffy, and William J. Swedish. 2014. Airport Capacity Profiles. Washington, DC: Federal Aviation Administration (FAA), https://www.faa.gov/airports/planning_capacity/profiles/media/Airport-Capacity-Profiles2014.pdf

Government Accountability Office (GAO). 1993. DOD's Mobility Requirements: Alternative Assumptions Could Affect Recommend Acquisition Plan. GAO/NSIAD-93-103. Washington, DC: GAO, http://chnm.gmu.edu/cipdigitalarchive/files/519_GAOMobilityRequirements.pdf

-1995. Bottom-Up Review: Analysis of Key DOD Assumptions. GAO/NSIAD-9556. Washington, DC: GAO.

. 2014. Climate Change Adaption: DoD Can Improve Infrastructure Planning and Processes to Better Account for Potential Impacts. GAO-14-446.

Gezer, M. 2001. Optimal Stationing of U.S. Army Forces in Korea. Master's Thesis. Monterey, CA: Naval Postgraduate School.

globalsecurity.org. 2011. Power Projection Platforms. Web page, http://www.globalsecurity.org/military/facility/ppp.htm

. Undated. Strategic Rail Corridor Network (STRACNET). Web page, http://www.globalsecurity.org/jhtml/jframe.html\#http://www.globalsecurity.org/military/facility ¿images/rr-stracnet-map-2.gif山

Headquarters, Department of the Army (HQDA). 2010. The United States Army Functional Concept for Movement and Maneuver 2016-2028. TRADOC Pam 525-3-6. Fort Monroe, VA: HQDA, http://www.tradoc.army.mil/tpubs/pams/tp525-3$6 . p d f$

. 2014. Army Deployment and Redeployment. Army Regulation (AR) 525-93. Washington, DC: HQDA, https://armypubs.army.mil/Search/ePubsSearch/ePubsSearchDownloadPage.aspx?doclD=090 $\underline{2 \mathrm{c} 85180010 \mathrm{~d} 36}$

. 2014. Military Operations: Army Deployment and Redeployment. Army Regulation 525-93. Washington, DC: HQDA, https://armypubs.army.mil/Search/ePubsSearch/ePubsSearchDownloadPage.aspx?docID=090 $\underline{2 \mathrm{c} 85180010 \mathrm{~d} 36}$

Institute for Water Resources (IWR). 2000. Inland Waterway Navigation: Value to the Nation. Alexandria, VA: U.S. Army Corps of Engineers (USACE) IWR, http://www.mvp.usace.army.mil/Portals/57/docs/Navigation/InlandWaterways-Value.pdf

Loerch, A. G., N. Boland, E. L. Johnson, and G. L. Nemhauser. 1996. Finding an optimal stationing policy for the U.S. Army in Europe after the force drawdown. Military Operations Research 2(4):39-51.

Melillo, Jerry M., Terese Richmond, and Gary W. Yohe (eds.) 2014. Climate Change Impacts in the 11 United States: The Third National Climate Assessment. U.S. Global Change Research Program. 
National Defense Authorization Act Year for Fiscal Year 1991. 1990. Public Law (PL) 101510. Stat. 1485, Section 29.

Office of the Assistant Secretary of the Army for Installations, Energy, and Environment (OASA[IE\&E]). 2016. Installations, Energy and Environment: Strategy 2025. Washington DC: OASA(IE\&E), http://www.asaie.army.mil/Public/IE/communicator/Strategy-2025.pdf

Office of the Secretary of Defense (OSD). 2013. Memorandum. Subject: Actions Required to Support Defense Mission Readiness in a Changing Climate (Draft). Washington, DC: OSD.

Singleton, J. G. 1991. Stationing United States Army Units to Bases: A Bi-Criteria Mixed Integer Programming Approach. Master's Thesis. Monterey, CA: Naval Postgraduate School.

Tarantino, William J. 1992. Modeling Closure of Army Materiel Command Installations: A Bi-Criteria Mixed Integer Programming Approach. Master's Thesis. Monterey, CA: Naval Postgraduate School.

Texas A\&M Transportation Institute (TTI). 2012. 2012 TTI's Urban Mobility Report. College Station, TX: Texas A\&M Transportation Institute, http://www.pagregion.com/Portals/0/documents/HumanServices/2012MobilityReport.pdf

Transportation Engineering Agency (TEA). Undated. IRRIS ${ }^{\circledR}$ : Serving the Military, Government, and Private Sector. Website, http://www.IRRIS.com

Trubenbach, Jason. (2014). Reinvigorating the Army's deployment readiness. Army Sustainment July-Aug 2014. 46(4):20. PB 700-14-04 DoA.

U.S. Department of Defense (DoD). 2012. Department of Defense FY 2012 Climate Change Adaptation Roadmap. Washington, DC: DoD, http://acclimatise.uk.com/login/uploaded/resources/Appendix\%20A\%20\%20DoD\%20Climate\%20Change\%20Adaption\%20Roadmap_20120918.pdf

. 2013. 2013 Report to Congress on Sustainable Ranges. Washington, DC: DoD, http://prhome.defense.gov/Portals/52/Documents/RFM/Readiness/docs/Sustainable\%20Ra nges\%202013\%20Report\%20to\%20Congress.pdf

2014. DoD Transportation Engineering. DoD Directive 4510.11. Washington, DC: Office of the Deputy Secretary of Defense, http://www.dtic.mil/whs/directives/corres/pdf/451011p.pdf

2014. Quadrennial Defense Review Report. Washington, DC: DoD, http://archive.defense.gov/pubs/2014_Quadrennial_Defense_Review.pdf

2016. Department of Defense Strategic Sustainability Performance Plan. Washington, DC: DoD, http://www.denix.osd.mil/sustainability/dodsspp/unassigned/department-of-defense-strategic-sustainability-performance-plan-fy-2016/

. 2016. Climate Change Adaptation and Resilience. DoD Directive 4715.21. Washington DC: Office of the Under Secretary of Defense for Acquisition, Technology, and Logistics, http://www.defense.gov/Portals/1/Documents/pubs/471521p.pdf 
U.S. Department of Transportation (USDOT). 2005. Coordinating Military Deployments on Roads and Highways: A Guide for State and Local Agencies. Washington, DC: USDOT, Federal Highway Administration (FHWA), http://www.ops.fhwa.dot.gov/publications/fhwahop05029/fhwahop05029.pdf

. 2009. Preliminary National Rail Plan. Washington, DC: USDOT, Federal Railroad Administration.

- 2013 Status of the Nation's Highways, Bridges, and Transit: Conditions \& Performance. Washington, DC: USDOT, Federal Highway Administration, https://www.fhwa.dot.gov/policy/2013cpr/

White House, The. 2015. Planning for Federal Sustainability in the Next Decade. Executive Order 13693. Washington DC: The White House, Office of the Press Secretary, https://www.whitehouse.gov/the-press-office/2015/03/19/executive-orderplanning-federal-sustainability-next-decade

2013. Fact Sheet: President Obama's Climate Action Plan. Washington DC: The White House, Office of the Press Secretary, https://www.whitehouse.gov/the-pressoffice/2013/06/25/fact-sheet-president-obama-s-climate-action-plan

2013. Preparing the United States for the Impacts of Climate Change. Executive Order (EO) 13653. Washington DC: The White House, Office of the Press Secretary, https://www.whitehouse.gov/the-press-office/2013/11/01/executive-orderpreparing-united-states-impacts-climate-change

Yardley, William. 8 February 2007. Gaping reminders of aging and crumbling pipes. The New York Times, http://www.nytimes.com/2007/02/08/us/08sink.html?_r=0 


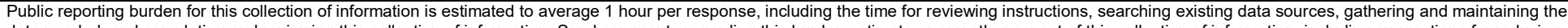

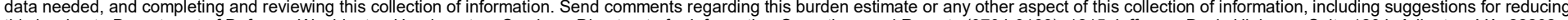

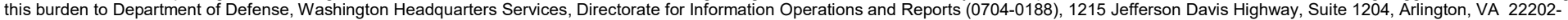

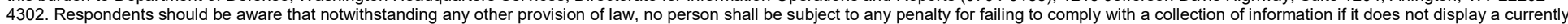
4302. Respondents should be aware that notwithstanding any other provision of law, no person shat
valid OMB control number. PLEASE DO NOT RETURN YOUR FORM TO THE ABOVE ADDRESS.

\begin{tabular}{l|l} 
valid OMB control number. PLEASE DO NOT RETURN YOUR FORM TO THE ABOVE ADDRESS. \\
\hline 1. REPORT DATE (DD-MM-YYYY) & 2. REPOR
\end{tabular}

\begin{tabular}{c|c} 
O2/24/2017 & Final \\
\hline
\end{tabular}

\section{TITLE AND SUBTITLE}

Deployment Infrastructure

Final

inal

1

TPE

E

rand

\section{AUTHOR(S)}

Natalie R. Myers, Michelle E. Swearingen, and James P. Miller

\section{PERFORMING ORGANIZATION NAME(S) AND ADDRESS(ES)}

U.S. Army Engineer Research and Development Center (ERDC)

Construction Engineering Research Laboratory (CERL)

PO Box 9005,

Champaign, IL 61826-9005

\section{SPONSORING/MONITORING AGENCY NAME(S) AND ADDRESS(ES)}

Office of the Assistant Secretary of the Army - Acquisition, Logistics, and Technology (ASA[ALT]) 2511 Jefferson Davis Highway

Arlington, VA 22202-3926

\section{DISTRIBUTION / AVAILABILITY STATEMENT}

Approved for public release; distribution is unlimited.
3. DATES COVERED (From - To)

5a. CONTRACT NUMBER

5b. GRANT NUMBER

5c. PROGRAM ELEMENT

5d. PROJECT NUMBER

5e. TASK NUMBER

5f. WORK UNIT NUMBER

R.INN.2015.26

8. PERFORMING ORGANIZATION REPORT NUMBER

ERDC/CERL TR-17-6

10. SPONSOR/MONITOR'S ACRONYM(S)

ASA(IE\&E)

11. SPONSOR/MONITOR'S REPORT $\operatorname{NUMBER(S)}$

\section{SUPPLEMENTARY NOTES}

\section{ABSTRACT}

The Army's approach to deployment has been evolving over the past 30 years in response to the global dispersion of threats coupled with the necessity to rapidly deploy, execute, and sustain operations worldwide. The result is a transformation from a forward-deployed Cold War force to a capabilities-based, power-projection force located largely in the United States. Increased deployment activity has become the normal operational standard within the continental United States, which may regularly affect the planning and operations for local authorities. The Army's deployment abilities depend on the readiness of all stake-holders including the resilience of transportation infrastructure systems. Yet, transportation infrastructures are being damaged by sea level rise, heavy downpours, and extreme heat - conditions that are anticipated to increase with continued climate change. This work investigated the degree to which climate change may impact the ability of Army installations to deploy forces in the future, and concluded that : (1) climate change may potentially pose a significant threat to future deployability, but that stationing decisions regarding deployment need not be influenced by climate change projections at this time.

\section{SUBJECT TERMS}

Transportation, Military, Transportation--Planning, United States. Army--Transportation, Deployment (Strategy), Military bases, Climatic changes

\begin{tabular}{|c|c|c|c|c|c|}
\hline \multicolumn{3}{|c|}{ 16. SECURITY CLASSIFICATION OF: } & \multirow{2}{*}{$\begin{array}{l}\text { 17. LIMITATION } \\
\text { OF ABSTRACT } \\
\text { SAR }\end{array}$} & \multirow{2}{*}{$\begin{array}{l}\text { 18. NUMBER } \\
\text { OF PAGES } \\
54\end{array}$} & 19a. NAME OF RESPONSIBLE PERSON \\
\hline $\begin{array}{l}\text { a. REPORT } \\
\text { Unclassified }\end{array}$ & $\begin{array}{l}\text { b. ABSTRACT } \\
\text { Unclassified }\end{array}$ & $\begin{array}{l}\text { c. THIS PAGE } \\
\text { Unclassified }\end{array}$ & & & $\begin{array}{l}\text { 19b. TELEPHONE NUMBER } \\
\text { (include area code) }\end{array}$ \\
\hline
\end{tabular}

